\title{
O Brasil que Portugal escreveu: pedagogia e política sem comemorações
}

\section{Carlota Boto}

Universidade Estadual Paulista

Universidade Presbiteriana Mackenzie
Neste dia, enquanto ali andaram, dançaram e bailaram sempre com os nossos, ao som dum tamboril dos nossos, em maneira que são muito mais nossos amigos que nós seus Pero Vaz de Caminha. Carta ao el-Rei D. Manuel sobre o achamento do Brasil. 1500

Dura inquietação d'alma e da vida

Fonte de desamparos e adultérios

Sagaz consumidora conhecida De fazendas, de reinos e de impérios! Chamam-te ilustre, chamam-te subida, Sendo digna de infames vitupérios;

Chamam-te Fama e Glória soberana, Nomes com quem se o povo néscio engana

Luís de Camões. Os lusíadas. 1572

\section{Introdução: raízes do Brasil na história cultural portuguesa}

A reflexão coletiva sobre os quinhentos anos do "achamento" do Brasil certamente contribuiu para o pen- samento acerca do lugar social e das intrincadas relações de nosso país nesse mundo hoje globalizado. Por mais que a globalização pareça ser, por vezes, a outra face do que há quinze anos chamaríamos de imperialismo, existe uma realidade que atualmente dá esse nome a um mundo cujo princípio (e a palavra princípio aqui significa tanto início quanto preceito) é o da acepção de um universo transnacional, com fronteiras e demarcações necessariamente deslocadas.

O debate sobre a trajetória da cultura brasileira em suas imbricações com a cultura portuguesa, ou, em outras palavras, a discussão a propósito dos quinhentos anos deixou bastante a desejar, tanto para portugueses quanto para brasileiros. Existe uma pedagogia das comemorações. Catroga destaca, a propósito do tema, que toda forma ritualista de evocar o passado visa, em alguma medida, perpetuá-lo pela rememoração. Criando-se e recriando-se uma dada memória nacional, os povos perfazem sua identidade coletiva no plano do imaginário, do simbólico. Quando representam e dão vida ao passado à luz dos recortes efetuados pelo momento presente, evidentemente produzem algo mais do que uma dívida de reconhecimento; tratar-se-ia, fundamentalmen- 
te da produção de consensos - nos termos de Catroga (1996, p. 548) -, "da hegemonização do poder simbólico, condição essencial de radicação de todo poder".

As comemorações dos quinhentos anos da descoberta do Brasil poderiam ser, genericamente, compreendidas como intento explícito de apresentar, pelo passado, as dimensões dos dois países no presente: a circunscrição geopolítica de Portugal no âmbito da Europa e o papel de um país como o Brasil no território hoje dito globalizado. Comemorar, sob tal enfoque, mais do que um ato de documentar, significaria tornar o passado um monumento, uma cristalização simbólica recriada e perpetuada pela homenagem. Haveria, nisso, um explícito papel justificativo e um desejo tácito de recordação pelo domínio do relato da morte. O monumento invoca o passado sem a pretensão de indagá-lo; trata-se apenas de reverenciá-lo, como o que se supõe dever fazer com um morto exemplar. Como bem destaca Le Goff sobre o tema, "o verbo memore significa fazer recordar, donde avisar, iluminar, instruir. O monumentum é [...] tudo aquilo que pode evocar o passado, perpetuar a recordação [...], ligar-se ao poder de perpetuação, voluntária ou involuntária, das sociedades históricas" (Le Goff, 1997, p. 95).

Comemorar, historicamente, em alguma medida requer essa construção de sentidos que, para emprestar as palavras de Certeau, dá lugar a um futuro. Redistribuir o passado seria, na provisoriedade da homenagem, uma encenação do outro, já que se está sempre simbolizando no relato inegáveis silêncios e inevitáveis lacunas. Se a escrita da história tem lugar de sepultamento ritualizado, existe uma função subjetiva diametralmente contrária quando se pretende comemorar: a ressurreição do objeto sepultado - "marcar um passado é dar lugar à morte, mas também distribuir o espaço das possibilidades, determinar negativamente aquilo que está por fazer e, conseqüentemente, utilizar a narratividade, que enterra os mortos, como um meio de estabelecer um lugar para os vivos" (Certeau, 1982, p. 107).

Em Portugal, o debate centrado no tema das comemorações das descobertas perpassou pela vontade de superar uma dada cultura laudatória do passado, que tanto mistifica quanto cristaliza esse mesmo passado, impedindo, por essa lógica, qualquer utopia ou prospecção do futuro. Em Portugal, evidentemente, a reflexão sobre o descobrimento do Brasil é um derivado do pensamento acerca da estratégia histórica das navegações. E notese que, desde o século XVIII, havia algum discurso da intelectualidade portuguesa que alertava para o fato de terem sido as navegações o fator primordial do afastamento de Portugal do circuito europeu, particularmente no que este tinha de potencial civilizatório. Portugal perdera com seu intento colonizador: perdeu porque se afastou da Europa; perdeu pelas enormes ondas migratórias. Pensar o Brasil também significou, na história de Portugal, o enfrentamento do intrincado fenômeno da emigração, entendendo esta como consequiência da insatisfação com o presente e com o país do presente. Tal tarefa não é, de maneira nenhuma, simples, até porque a problematização do futuro português requer, por si, algum acerto de contas com seu passado de metrópole do além-mar.

Como bem destaca Eduardo Lourenço, o Brasil, por sua vez, muito cedo optou pelo afastamento de suas raízes portuguesas: para afirmar sua identidade, de alguma maneira, o brasileiro recusou a herança portuguesa, distanciou-se dela e viveu, nessa distância, suas próprias mitologias culturais. A maior delas, como observa o escritor português, seria a seguinte:

A bem dizer, o Brasil vive-se, e imagina-se, naturalmente inscrito num espaço de que ele é o centro e a circunferência. Pode dar-se ao luxo de não ter mais exterior do que o seu interior, já tão difícil de assumir. Mas não pode impedir de ser visto, de saber que os outros o vêem e, em particular, que é, em termos de potência e representatividade, lusófono e centro empírico de uma comunidade que tem como único elo incontornável a língua que lhe dá um lugar à parte no continente a que pertence. (Lourenço, 1999, p. 171)

Na pedagogia mitificada das comemorações, Portugal cria para si a imagem de um povo dotado, quase por essência, da vocação universalista. O Brasil, em contrapartida, ao não se reconhecer como protagonista da narrativa que conta de sua história, pensa sempre um conto inventado, de tudo aquilo que poderia ter sido, se os portugueses não tivessem chegado até aqui, se a invasão holandesa tivesse dado certo, se o modo de colonizar fosse à maneira inglesa; sempre um se, que não 
foi... Confrontar-se com a história produzida, divulgada e conhecida, ainda que, por vezes, bastante vulgarizada, parece violar a própria essência do ideário de nação, no caso brasileiro. Rejeitando, portanto, essa herança - de costas para o passado - e em busca de sinalização de um futuro produzido a partir sabe-se lá de qual memória, o Brasil, em seu universo de símbolos e imagens diz Eduardo Lourenço -, elege e condena, no mesmo passado colonial, carrascos e culpados: culpados do que passou, do que se passa e, talvez, do que se passará. É como se a história fosse inevitavelmente determinada e finalista, havendo nela um sentido inscrito no ponto de partida.

Pode-se dizer que tanto a visão portuguesa quanto a interpretação brasileira desses quinhentos anos de contato são reféns de seus próprios interesses diante do futuro. Em ambos os casos, sacrifica-se a história em nome da coerência de um relato passível de ser simples e pedagogicamente apreendido. Como réplica à versão portuguesa, o Brasil escancara as misérias de seu percurso colonial. Em tom de recusa da versão brasileira, os portugueses recordam que - a despeito da "rasura consciente ou inconsciente de suas origens lusitanas" (Lourenço, 1999, p. 149), a despeito de um dado parricídio histórico engendrado como autodefesa de sua própria mitologia cultural -, caberia ao Brasil assumir que, se houve efetivamente no trajeto da colônia destruição de povos e fraturas de culturas (e a todos parece inegável esse fato), "os portugueses do Brasil - ou seja, os atores de que o Brasil e os brasileiros são a expressão - foram os agentes desse genocídio" (Lourenço, 1999, p. 149). Isso significa enfrentar o doloroso fato de que os protagonistas do genocídio, desde muito cedo, foram os portugueses que para cá vieram e seus descendentes. Os outros portugueses, que permaneceram em território lusitano, mantiveram-se lá, em Portugal. Com isso, Eduardo Lourenço arremata com a provocante insinuação de que teriam sido, portanto, os nossos antepassados e não os deles - portugueses de hoje - que procederam à chacina de povos e de culturas.

Com um tom de apologia ao modelo colonial à portuguesa, em Sermão pelo bom sucesso das armas de Portugal contra as da Holanda, o Padre Vieira, em 1640, procurava justificar a primazia da ocupação dos portugueses e a conseqüente ilegitimidade dos invasores holandeses perante aquela terra já conquistada. Dirigindo o discurso a Deus, Vieira dirá que entregar o Brasil aos portugueses teria sido antes um ato de ira do que de benevolência do Criador:

Tirais o Brasil aos portugueses, que assim estas terras vastíssimas, como as remotíssimas do Oriente, as conquistaram à custa de tantas vidas e tanto sangue, mais para dilatar vosso nome e vossa Fé que por amplificar e estender seu império [...] Que a larga mão com que nos destes tantos domínios e reinos não foram mercês de vossa liberalidade, senão cautela e dissimulação de vossa ira, para aqui fora e longe de nossa Pátria nos matardes, nos destruirdes, nos acabardes de todo. Se esta havia de ser a paga e o fruto de nossos trabalhos, para que foi o derramar tanto e tão ilustre sangue nestas conquistas? Para que abrimos os mares nunca dantes navegados? [...] $\mathrm{E}$ depois de tantas e tão lastimosas mortes, ou nas praias desertas sem sepultura, ou sepultados nas entranhas dos alarves, das feras, dos peixes, que as terras que assim ganhamos, as hajamos de perder assim? Oh! Quanto melhor fora nunca conseguir nem intentar tais empresas! (Vieira, 1985, p. 39)

É natural que o imaginário acerca do Brasil tenha sempre repercutido em Portugal, para o bem ou para o mal. É também compreensível que não sejam convergentes as visões e versões do pacto colonial, quando se colocam frente a frente relatos dos colonizadores e dos colonizados. O objetivo deste trabalho é o de oferecer subsídios para a identificação de leituras de Brasil feitas em território português no período compreendido entre o final do século XVIII e o início do século XX.

António Nunes Ribeiro Sanches, considerado por muitos como o mentor intelectual das reformas pombalinas, assinalava, em meados do século XVIII, nas suas famosas Cartas sobre a educação da mocidade, que, ao contrário das riquezas da África e da Índia Oriental, as riquezas do Brasil nunca chegavam às terras portuguesas. Tal análise, já na altura, deixava transparecer algum ressentimento quanto a uma dada autonomização precoce da colônia Brasil quando comparada ao restante do império colonial português.

No mesmo século XVIII, D. Luís da Cunha, em seu Testamento político, sublinharia o êxodo populacional para o Brasil como um elemento da fragilização históri- 
ca do reino português em seu percurso de desenvolvimento. Para aquele arauto da política pombalina, a estreiteza das fronteiras portuguesas constituía indubitavelmente um de seus mais visíveis limites, particularmente quando comparada à proporção dos países vizinhos. Contudo, o lugar geográfico do ultra-ocidente ocupado pela Península Ibérica não deixava de ser estratégico para a criação de um dado sentido de vizinhança com o mar; o que, por seu turno, acarretaria uma das mais dolorosas sangrias nacionais. A emigração, assim acompanhada da religiosidade excessiva e historicamente perniciosa, do decorrente papel da Inquisição em Portugal e do desequilíbrio do comércio -, seria tomada, por D. Luís da Cunha, como um dos males que afligiam o reino:

A segunda sangria, que não deixa de enfraquecer o corpo do Estado, e a que não acho remédio, é o socorro da gente que anualmente se manda para a Índia, sem o qual não se poderia sustentar. E como uns morrem na viagem e o que mais é, outros se fazem frades, deveria ser um ponto de instrução do vice-rei não permitir que nenhum soldado, que fosse de Portugal, entrasse em alguma religião, pois que para se salvarem é bastante a do seu ofício. A este prejuízo se segue o de que pela mesma razão vêm a faltar os marinheiros que debandam e deixam as suas mulheres, de que poderiam ter muitos filhos. O Brasil não sangra menos a Portugal, porque sem embargo de já não ser livre a cada qual passar àquele Estado sem passaporte, conforme ouço dizer, contudo furtivamente se embarcam os que ao cheiro das minas querem lá ir buscar sua vida. (Cunha, 1976, p. 74)

Para Boaventura de Souza Santos, foi o próprio acentrismo português, ou seja, sua dificuldade quanto à delimitação das fronteiras coloniais uma das características do modo de colonização lusitano. A hipótese básica gizada pelo autor remete à acepção de "zona fronteiriça" como a característica mais plena de uma específica forma cultural, traduzida substancialmente na facilidade de apropriação no distanciamento, de incorporação na rejeição e no sincretismo que recusa o outro, ao mesmo tempo que o absorve. Nesse sentido, a própria conotação de cultura portuguesa estaria modificada à partida, posto que o Estado português não teria desempenhado a contento a tarefa motriz dos estados nacionais euro- peus da modernidade; qual seja, a de, simultaneamente, criar o efeito de distinção e, portanto, de diferenciação cultural em face do seu exterior, produzindo, pela margem oposta, táticas e estratégias de homogeneização no interior do território nacional. No parecer do sociólogo Souza Santos:

O fato de o Estado português não ter desempenhado cabalmente nenhuma das duas funções - diferenciação face ao exterior e homogeneização interna - teve um impacto decisivo na cultura dos Portugueses, o qual consistiu em as espáciotemporalidades culturais local e transnacional terem sido sempre mais fortes do que a espácio-temporalidade nacional. Assim, por um lado, a nossa cultura nunca se conseguiu diferenciar totalmente perante culturas exteriores, no que configurou um défice de identidade pela diferenciação. Por outro lado, a nossa cultura manteve uma enorme heterogeneidade interna, no que configurou um défice de identidade pela homogeneidade. Note-se que esses défices são-nos apenas quando vistos da espácio-temporalidade cultural nacional. Os espaços locais e transnacionais da cultura portuguesa foram sempre muito ricos; só o espaço intermediário, nacional, foi e é deficitário. [...] Portugal estava demasiado próximo das suas colônias para ser plenamente europeu e, perante estas, estava demasiado longe da Europa para poder ser um colonizador conseqüente. Enquanto cultura européia, a cultura portuguesa foi uma periferia que, como tal, assumiu mal o papel de centro nas periferias não-européias da Europa. Daí o acentrismo característico da cultura portuguesa que se traduz numa dificuldade de diferenciação face ao exterior e numa dificuldade de identificação no interior de si mesma. (Santos, 1993, p. 33)

A idéia de uma cultura de fronteira como identidade essencial portuguesa é trabalhada por Santos como uma via de mão dupla, posto que, se, em alguma medida, tende à dramatização e à carnavalização que subvertem os modos de ser quotidianos, em contrapartida, dificulta a demarcação de um referencial de centro, fato que, por si mesmo, convidaria ao cosmopolitismo: “A leveza da zona fronteiriça torna-a muito sensível aos ventos. É uma porta de vai-vem, e como tal nunca está escancarada, nem nunca está fechada" (Santos, 1993, p. 36). Assim concluindo, o autor observa que a cultura de fronteira carrega consigo a força de sua metáfora; metáfora que acompanharia a "vocação" de um Portu- 
gal marítimo; metáfora que, de alguma maneira, chegaria até nós pelas imagens de um Brasil construído à portuguesa, por portugueses...

\section{Imagensdo Brasil como herdeiro incauto da expansão portuguesa}

A leitura escolar constituía estratégia privilegiada para representar Portugal, para fazer falar um Portugal apresentado em uníssono aos corações infantis e juvenis. A escola visava não apenas a levar a conhecer, mas, sobretudo, a fazer amar um país que teria pedagogicamente firmado sua identidade nos corações e nas mentes infantis. Com vistas a fabricar e consolidar a acepção patriótica, havia alguma urgência para que fossem compartilhadas visões e versões de mundo, crenças, expectativas, relatos míticos e projeções de história. A escolarização - que veicula, a seu modo, a cultura letrada, e que existe basicamente em função disso - apropria-se de uma maneira toda sua dessa mesma cultura, pretensamente capacitando gerações para efetuar a leitura autorizada e pretendida da sociedade presente. A escola, pois, supostamente, organiza um corpus de conhecimento unitário e coerente, voltado para a explicação da língua e das linguagens do país.

Organizando e sistematizando a realidade social, o registro escolar passa por "trechos selecionados" de leitura; estes, por sua vez, constituem frações do relato autorizado do mundo que se pretende contar às crianças, com a finalidade de incutir determinados estados de espírito e de comportamento desejados pelas gerações adultas, particularmente pelas gerações adultas em posição de poder no contexto social. A escola, que periodiza a infância, periodiza também seu passado sócio-histórico. A realidade social, tal como vem registrada nos compêndios didáticos, coloca-se, assim, como a versão recomendada para compreensão.

Abarcando referências culturais da sociedade na qual se inscreve, a escolarização edifica a orientação de obediência e acatamento de normas e regras da vida. Ao pretender retratar modelos exemplares - exatamente para que sirvam de exemplo - a escola confere prioridade à gesta do passado, remontando à sua grandeza modelar e ao heroísmo de seus atores, com a finalidade explícita de que as novas gerações passem a tomar esse passado como referência a ser rememorada. O ritual escolar remete-se, por causa disso, a toda uma mitologia cultural, que recria tempos que pretende reencontrar.

Os manuais didáticos do século XIX apresentam a descoberta do Brasil como um marco na história de Portugal. Evocam-se, freqüentemente, imagens da chegada de Cabral, o espanto dos nativos, as velas, os mastros e o cenário idílico do momento tomado como fundador. De alguma maneira, a narrativa da chegada dos portugueses passava pela escola. Às imagens da natureza, seguiam-se as descrições dos indígenas - sempre por analogia: como pareciam com os asiáticos, ou como diferiam dos africanos. Nitidamente, visualiza-se o olhar do descobridor como tônica da história construída; um relato que retoma, em alguma medida, o teor da carta de Caminha e que, apropriado por este ou aquele escritor, pretendia contar a grandeza do feito às vindouras gerações de jovens portugueses.

Em 1903, Trindade Coelho editava seu Terceiro livro de leitura, pela Livraria Aillaud. Tratava-se de um compêndio para uso das crianças de escola primária e se destacava exatamente pela exaltação patriótica. A primeira lição expunha a bandeira de Portugal e o Hino. A seguir, explicavam-se os laços de sangue e a constituição da família. Depois, vinham trechos de $O s$ Lusíadas. E a pouco e pouco o compêndio combinava a preocupação de instruir com o notório intento de aprendizado de uma determinada compreensão de Portugal, um país que deveria estar desenhado para as crianças no que parecia conter de vocação e de caráter heróico. O autor não consegue se eximir de parecer laudatório sobre o universalismo contido na própria identificação da especificidade de seu país. O mar e a vocação para o além-mar pareciam ser o próprio destino reservado a Portugal.

A Europa é compreendida como aquilo que circunda, o que está em volta; em volta de Portugal e de tudo o que os portugueses descobriam: "os dois milhões de portugueses multiplicam-se, como por encanto, enchendo as armadas que saem de Lisboa para as conquistas. É um sair e entrar de navios, uma atividade febril que aturde; e ainda que muitos não voltem, os que regressam alimentam a febre e inundam a Casa da Índia com as 
riquezas das novas terras descobertas" (Coelho, 1903, p. 326-327). As especiarias trazidas transformavam Lisboa no "empório do comércio europeu", e naquela pequena capital de pequeno território, por um momento, concentrar-se-iam "todas as ambições, todos os entusiasmos, todos os ódios e todos os amores da Europa" (Coelho, 1903, p. 326-327).

Nos termos do relato didático, a nova situação portuguesa, como efeito das navegações, atraiu reis, príncipes, embaixadores de todos os países europeus, fosse pela grandeza do feito admirado, fosse pela implicação material da riqueza por ele alcançada. Sucede que, sendo assim, há toda uma idealização do suposto passado heróico, fonte de enaltecimento e de orgulho nacional. Sobre a entrada e o lugar desempenhado pelos portugueses perante os povos encontrados, utiliza-se a categoria de "missão educadora", mediante a qual justificavam-se o domínio e a tutela de povos apresentados como incapazes de se governar por uma razão autônoma povos "incultos". O texto didático, sobre o tema, dirá que o descobrimento do Brasil não foi a máxima proeza da navegação portuguesa. Este epíteto ficaria para a viagem de Vasco da Gama, cantada por Camões. O que distinguiria o caso do Brasil era, então, a existência de um processo muito singular de colonização: uma conquista que era antes fruto de persuasão do que de níveis extremos de coerção; uma coerção cordial, talvez...

Mas, se não foi a reluzente glória da nação portuguesa, valeu mais, muito mais, sob outro aspecto, do que tudo que fizéramos antes e do que tudo quanto fizemos depois. Descobrir é muito; civilizar é tudo. A colonização do Brasil é, para Portugal, a máxima honra entre todos os títulos da sua alta benemerência histórica. Esta é, em verdade, a suprema honra do nosso gênio. (Coelho, 1903, p. 335)

Os sentidos inscritos na ação colonizadora estariam contidos na aventura marítima. A ação dos portugueses é apresentada como se houvesse uma coerência lógica entre o modo de chegar e o modo de permanecer; como se a conquista fosse um natural desdobramento da descoberta; e como se o percurso da colonização tivesse o mesmo tom luminoso da aventura e da ousadia das navegações. O compêndio redigido por Antonio Maria Seabra d'Albuquerque, sob o título Selecta da infância
- editado na Imprensa da Universidade de Coimbra, e utilizado em inúmeras escolas primárias portuguesas a partir de 1870 -, chegava a fazer uma apologia do mar, em nome do que se acreditava ter sido seu papel para a escrita da história portuguesa. Parece curioso que a própria idéia que aqui se transmite de história tem como objeto a demarcação de um processo de identificação para a nação; mas é como se a identidade estivesse absolutamente inscrita no passado e até, em última instância, na circunscrição geográfica - e como se, conseqüentemente, não se houvesse reservado lugar algum ao futuro:

[...] nenhum coração verdadeiramente português deixará de pulsar de puro gozo em frente do elemento que recorda a parte interessante que teve o nosso país no estado atual do mundo civilizado. Ao mar deve Portugal o seu antigo poderio; develhe as páginas mais brilhantes da sua história: dever-lhe-á talvez ainda a importância que no futuro venha a ter. Se a Inglaterra é uma nação poderosa, porque as suas províncias são em grande parte banhadas pelo Oceano, por que o não há-de vir a ser, como já foi, o país que é quase todo um extenso litoral?

(Albuquerque, 1870, p. 131-132)

No intervalo entre um passado concluído e um futuro que não se conseguia planejar, Portugal transmitia de si próprio a versão metafórica de um país com o mar por vocação. A preocupação com a indefinição de si mesmo produzia o outro. Portugal lançara-se ao mar; e, vencedor no empreendimento, passava a dar representações de si próprio e de seu lugar no continente. Nesse imaginário, evidentemente mesclavam-se sentimentos contraditórios: o da percepção do desafio, entre o medo e a audácia; o impacto e deslumbramento iniciais para com as novas terras e povos descobertos, e o temor e sentido de superioridade que vinham em seguida... A própria perspectiva da ação civilizatória remete, em larga escala, para um recorte cultural.É o modo como eu concebo a mim mesmo que me leva a nomear o outro. $\mathrm{O}$ outro, portanto, só existe pelo contraponto, pela distinção, pela comparação. É assim também com os povos. E, em alguma medida, o Brasil, e mesmo o Brasil independente, ganharia legitimidade de existência perante a sua analogia e suposta filiação com Portugal.

A Nova selecta portugueza, escrita, naquele mesmo final de século, por dois professores do Liceu Cen- 
tral do Porto - João Moreira e João Corrêa - dirigia-se explicitamente para o uso das aulas de português e de literatura de alunos de Liceu. Tratava-se de um manual didático, de feição enciclopédica, no qual inúmeros eram os temas considerados instrutivos apresentados para dirigir a leitura. Evidentemente, o assunto das descobertas constituía uma das lições do referido compêndio. Ao cabo da eloqüente descrição das terras do Brasil que os portugueses encontraram, passa-se, de imediato, a um parágrafo final de avaliação da Independência:

Hoje, o Brasil, vastíssimo império, vivido, esperançoso e livre. Emancipado da metrópole não só pelos sucessos políticos que se realizaram no primeiro quartel do século em que vivemos, mas ainda pela lógica natural do progresso das sociedades, está destinado pela sua posição geográfica, pela excelência do clima, pelas riquezas que possui e pelo patriotismo dos seus habitantes, a desempenhar um grande papel na história do novo mundo. Possa o povo infante, filho e em tudo descendente d'uma nação pequena, mas nobilíssima, viver e prosperar por muitos séculos, dando exemplos de sabedoria e de humanidade às velhas monarquias da Europa, que se julgam mais civilizadas, e que só têm mais poder ou fortuna. (Moreira \& Correa, s/d, p. 38)

Havia, finalmente, manuais didáticos que apresentavam, ao lado dos aspectos históricos, as características físicas e geográficas do Brasil, sua população, clima, vegetação e extensão: "a natureza apresenta-se nesse país pródiga em tudo quanto possa concorrer para tornálo mais tarde um dos impérios mais poderosos e opulentos" (Coelho, 1857, p. 250). De qualquer modo, as idéias de Brasil eram habitualmente combinadas com a profecia de um futuro radioso, de grande nação protagonizando o cenário mundial. Portugal era visto como pátria gloriosa e orgulhosa de seu passado, que construíra a terra do futuro; e o Brasil era, até certo ponto, o consolo imaginado para "lavar a alma" de sua mãe-pátria decadente.

Portugal reconhecia a si próprio como nação marcada pelo lastro da obediência e respeito à religião, aos reis e às leis; pátria que ofereceu ao mundo ocidental "esforçados combatentes, que, sempre valorosos e intrépidos, enristaram eles suas lanças para a conquista, e desenrolaram suas velas para a descoberta" (Coelho, 1857, p. 285). Valentes e constantes no trabalho, o aban- dono do continente pelas colônias teria, contudo, produzido um efeito nefasto para os portugueses, particularmente no que toca ao desenvolvimento e à prosperidade interna do reino. A decadência, dessa forma, seria, em alguma medida, o efeito direto e imediato das navegações: sendo estas compreendidas como aquilo que afastou Portugal da Europa e dos povos civilizados, aproximando-o das conquistadas terras incautas e incultas:

Se Portugal deixou de ser hoje a princesa das nações, como se lhe outrora chamara, face a face com sua decadência, é ainda assim uma nação briosa, tanto quanto lho permite sua importância política. O português ama em excesso a sua pátria, e apesar da normal placidez de seu caráter será ainda arrebatado e entusiasta sempre que houver mister de defender a sua independência: o jugo estrangeiro não o reconhece, aceitao em quanto não o pode abater. O português é por índole caritativo para com os seus próprios inimigos, e generoso até mesmo na privação da fortuna. É extremamente repugnante a injustiça que vários escritores estrangeiros nos têm feito tratando este mesmo assunto; mas seja-lhes ela de algum modo relevada em atenção à crassa ignorância que geralmente hão manifestado em todas as ocasiões que tem proposto avaliar as coisas que dizem respeito a esta nação. (Coelho, 1857, p. 285)

\section{O Brasil colocado em revista: paisagensda terra}

Havia uma concepção de história muito presente em Portugal durante todo o decorrer do século XIX. Tratava-se de compreender a nação mediante o que se supunha ser um regresso às suas origens, um gesto de regeneração; passível de conduzir o país, de sua existência momentânea, ao que efetivamente seria sua essência (Catroga, 1996, p. 39). Supunha-se, assim, uma inteligibilidade histórica que recusava qualquer nível de incerteza, como se a história devesse efetivamente se transformar na ciência que regra o acaso, que transpõe os obstáculos da indeterminação do futuro, e que passa, conseqüentemente, a prever e a prover o mesmo futuro. Havia, portanto, um tom explícito de imanência e de teleologia, direcionado à luz de um dado finalismo, o qual, por suposto, conferiria sentido à lógica do tempo.

Alexandre Herculano preocupara-se em dar voz ao regime constitucional e liberal que estava em curso no 
cenário português desde 1834. Para tanto, entendia ser fundamental a formação de uma opinião pública esclarecida e preparada para fazer eco ao novo tempo. O veículo primeiro da estratégia de Herculano para dar o tom desse novo Portugal era exatamente o de propugnar a instrução escolar para as crianças e a instrução da imprensa periódica para os adultos. Havia de se formar uma nova geração de leitores competentes - aqueles que efetivamente estariam aptos para ler e ensinar a reler a sociedade; daí a caracterização da iniciativa da revista O Panorama, auto-intitulando-se como "sociedade propagadora dos conhecimentos úteis".

Com um cariz enciclopédico e um conteúdo eminentemente liberal, a revista continha informações sobre aspectos culturais e estatísticos dos diferentes países europeus e do continente americano, muito particularmente do Brasil. Eram páginas de direito que se seguiam a análises históricas, acompanhadas por descrições geográficas ou comentários de costumes típicos deste ou daquele povo, desta ou daquela região. O objetivo explícito era o de combinar o efeito da distração com a finalidade da informação instrutiva. Daí a preocupação literária ser subordinada a uma dada pedagogia política. Nos termos de Fernando Catroga, "fosse através de ensaios, ou mediante novelas e romances históricos, O Panorama carreou informações e gizou quadros cronológicos que os seus leitores 'burgueses' podiam ostentar ou antepor à cultura tradicionalista" (Catroga, 1996, p. 42). Visava-se, assim, por tal didática estratégica na orientação impressa para "leitura de revista", conformar uma nova sensibilidade, um novo recorte mental para a formação de símbolos e de valores da burguesia e das camadas médias da sociedade portuguesa da época.

O Panorama compreendia a si próprio como um veículo de ensinamentos úteis. A idéia era, por meio da leitura educativa, formar percepções e modos de ver das gerações adultas. Havia, como vimos, nitidamente, um propósito pedagógico no projeto enciclopédico desse periódico, dirigido, a princípio, por Alexandre Herculano. O objetivo da iniciativa, que dizia pretender combinar os aspectos literários e os instrutivos, era o de fazer com que a leitura pudesse alcançar populações maduras, que já haviam há muito deixado a escola, ou que nem houvessem passado por ela, ainda que soubessem ler. Inspirando-se na grande Enciclopédia francesa, tratava-se de fazer com que as luzes descessem ao povo comum, por degraus, de tal modo que a atividade leitora compusesse um literal panorama, capaz de combinar aprendizado e diversão. Com isso, pretendia-se esclarecer e civilizar; ensinar e persuadir; divulgar e criar comportamentos...

$\mathrm{Na}$ edição de maio de 1839, assinada por Cunha Rivara, coluna específica d' O Panorama intitulada Brasil abordava o tema dos indígenas, primeiramente buscando compreender os porquês do "exagerado entusiasmo" dos portugueses para com aqueles que haviam sido os originais habitantes da terra descoberta. O primeiro aspecto destacado pelo articulista era exatamente o da diversidade entre o novo mundo descoberto e o velho mundo europeu. O contraste seria, em si mesmo, a razão da curiosidade; e, com ela, do desejo de compreensão dos hábitos, dos gostos, dos ritos, dos desejos e das crenças... Após longa descrição em que procurava explicitar as distinções e proximidades entre Tupinambá, Potiguar, Caité, Tupiniquim, Carijó e outros, o articulista destaca como ponto comum o fato de todos esses povos falarem supostamente uma mesma língua, com algumas variantes e poucas discrepâncias. Tal língua seria, antes de tudo, fácil, suave e elegante; embora ela não contivesse, em seu repertório, nem fé, nem lei, nem rei...

Os portugueses a aprenderam logo e os missionários a reduziram a arte escrita e a ensinavam. A respeito dessa língua diz um dos nossos mais estimáveis escritores das coisas do Brasil: “Tem muita graça quando falam, mormente as mulheres. São mui compendiosos na forma da linguagem e mui copiosos no seu orar; mas faltam-lhes três letras das do A, B, $\mathrm{C}$, que são $F, L e R$, coisa muito para se notar, porque se não têm $F$ é porque não têm $f e ́$ em nenhuma coisa que adorem, nem os nascidos entre os cristãos e doutrinados pelos padres da Companhia têm fé em Deus Nosso Senhor, nem têm verdade, nem lealdade a nenhuma pessoa que lhes faça bem. E se não têm $L$ na sua pronunciação é porque não têm lei nenhuma que guardar, nem preceitos para se governarem, e cada um faz a lei a seu modo, e ao som de sua vontade, sem haver entre eles reis com que se governem, nem têm leis uns com os outros. E se não têm esta letra $R$ na sua pronunciação é porque não têm 
rei que os reja e a quem obedeçam, nem obedecem a ninguém, nem o pai ao filho, nem o filho ao pai, e cada um vive ao som da sua vontade [...]". (O Panorama, 4-5-1839, p. 325)

A mesma revista $O$ Panorama, em agosto de 1857, questionaria a premissa segundo a qual os indígenas teriam sido os mais puros e primeiros artífices da nacionalidade brasileira. Tratava-se de uma série de artigos, sob o título Os índios perante a nacionalidade brasileira, escritos por alguém que assinava pela abreviatura "F. A. de V.". A hipótese do autor passava pelo questionamento da suposta primazia conferida pela literatura brasileira aos indígenas. Tidos como primeiros habitantes do território, tal interpretação fazia supor que a verdadeira nacionalidade brasileira seria mais tributária desses nativos do que dos africanos ou - o que parecia pior dos portugueses. Ora, o artigo procurava cercar o tema, revelando que havia restado menor representatividade genética de traços indígenas do que de traços da raça negra, por exemplo. Para cercar o tema, o articulista propunha-se a indagar alguns aspectos tomados como essenciais para a constituição de nossa formação social.

Primeiramente, os tupis eram apresentados como os últimos invasores do território hoje brasileiro, vivendo como nômades e, portanto, como aqueles que apenas desfrutavam da terra sem preocupações de colonizá-la. Além disso, muitas tribos selvagens praticavam canibalismo:

Mantinham a antropofagia; desfiguravam-se horrivelmente, esburacando a cara; andavam geralmente nus; experimentavam toda sorte de privações, passando até por vezes fomes, por excesso de imprevidência; não castigavam vícios, nem premiavam virtudes; ou antes não reconheciam estas nem aqueles. Tratavam as mulheres como escravas e eram viciosos contra naturam. Suas povoações consistiam em uns poucos de grandes ranchos ou casarões, em que viviam aquartelados, todos juntos, sem que houvesse repartimentos interiores; não usavam de nenhum metal. Empreendiam a guerra por vingança ou por satisfazer outros instintos, ou os apetites do chefe e senhor despótico, que era o que a si se proclamava tal, por mais valentão, enquanto outro, com alguma seqüela, não lhe disputava o lugar, perpetuando a guerra civil. Os prisioneiros eram sacrificados em meio de danças e bacanais. Por outra: viviam (e alguns vivem ainda) no primitivo estado do homem caído e manchado; isto é, no estado natural de família ou tribo, sem leis preventivas superiores às paixões momentâneas, nem penas contra os infratores dessas leis. (O Panorama, 228-1857, p. 266)

Nessa trilha, os indígenas - vivendo em estado natural - eram caracterizados pelo seu elevado grau de barbárie e de degeneração de hábitos, chegando ao limite da degradação humana posto na ação de seu próprio auto-extermínio. A função colonizadora, cristã e missionária viria, portanto, com um caráter redentor, que, ao mesmo tempo, conferia moralidade e hábitos de vida civil. Tratava-se de substituir o estado natural pela necessária e valorosa sociedade do mundo "civilizado", como a única alternativa histórica e filosoficamente possível e defensável para radicar na espécie hábitos de convívio humano nos termos do desenvolvimento de costumes; o que não aconteceria sem um certo nível de sujeição e de obediência: "A escravidão e a subordinação são o primeiro passo para a civilização das nações disse com sua admirável filosofia e coragem o virtuoso e sábio bispo brasileiro Azeredo Coutinho" (O Panora$m a, 22-8-1857$, p. 268).

O emprego da força era, portanto, justificado como sendo imprescindível, ainda que doloroso historicamente. Civilizar supunha o encontro, mas também o desencontro - jogos, distanciamentos e jugos de culturas, umas sobre as outras. Justificava-se o domínio alegando que a Humanidade sempre foi assim; e, por isso, não haveria nem como e nem por quê ser de outra forma. A civilização, supondo o recorte cultural, produzia representações de mundo autorizadas, com comunidades de convenções e protocolos de significados. Para tanto, o olhar do outro era recusado e sua forma de vida apontada como contrária ao ponto fixo tomado por parâmetro: tudo o que diverge do meu modo de compreender a cultura deixa de ser cultura. Assim a cultura européia propugnava sua vocação universalista, como se houvesse de fato a possibilidade de, a partir de algum ponto fixo, se falar em níveis de cultura geral. Assim compreendendo, a cultura que nos descobria encobria seu outro, ao pretender desvelá-lo. Ao fazer isso, supunha entregar poções culturais para sedimentar uma aculturação não apenas percebida como legítima, mas fundamentalmente como desejável. 
Sobre a não proeminência da cultura indígena como edificadora maior dos sentidos da cultura brasileira, ainda em meados do século XIX, vários artigos d'O Panora$m a$ argumentavam, recordando a inegável exterminação histórica dos indígenas e a conseqüente ausência de vestígios fisionômicos dessa raça, "porque eram os índios em tão pequeno número no país que foram absorvidos fisicamente pelos outros dois elementos como o foram moralmente" (O Panorama, 22-8-1857, p. 277). Além disso, para identificar a supremacia do elemento português, seria suficiente indagar os sobrenomes dos brasileiros. Tomando a língua como primado da conquista cultural, os brasileiros não se reconheceriam por palavras africanas ou guaranis. A língua, nesse sentido, torna-se pátria, porque veículo comum de comunicação. Mesmo assim, reconhece-se que os dizeres do Brasil não se confundiam inteiramente com o falar dos portugueses, à moda dos portugueses: o filho emancipara-se, embora se assemelhasse ao pátrio poder de Portugal; embora falasse sua língua; embora praticasse sua religião. Assim, pela língua, pela lei, pela religião, o Brasil se teria firmado à imagem e à semelhança de Portugal.

Claro está que, se o elemento europeu é o que essencialmente constitui a nacionalidade atual, e com mais razão (pela vinda de novos colonos da Europa) constituirá a futura, é com esse elemento cristão e civilizador que principalmente devem andar abraçadas as antigas glórias da pátria, e por conseguinte a história nacional [...]. Um índio que escrevesse a história da conquista não teria que cansar-se muito para nos dizer que para ele tudo quanto haviam feito os europeus fora violência, ilegitimidade, usurpação; e, com inscrever estas três palavras no frontispício de um livro em branco, satisfaria a sua missão, sem rebuscar documentos nos arquivos inimigos; pois que lhe faltaria tempo para contar-nos a miséria, degradação e antropofagia dos seus. Eis a história nacional se os índios do mato conquistassem todo o Brasil [...]. Daqui até a adorar historicamente a selvageria vai muita distância. Nós também estudamos tudo quanto respeitava aos holandeses, e, sem embargo, não simpatizamos com o seu domínio e aplaudimos a sua expulsão. (O Panorama, 22-8-1857, p. 278)

A preocupação com a afirmação da preponderância do elemento português na constituição da nacionalidade brasileira perpassa, pois, os significados pedagó- gicos e as mensagens didáticas expressas em discursos que falavam do Brasil. Ao fazer isso, inevitavelmente faziam falar um dado Brasil - inventando tradições, editando representações e protocolos de leitura, imprimindo cenários de imaginações. Havia um desejo de paternidade para com a principal e mais importante ex-colônia, a que se havia emancipado pelas mãos de um português, e que constituía episódio de vulto na história de sua antiga metrópole. Por causa da preocupação que tinham com a própria identidade, era assim que os portugueses procuravam nomear e interpretar o Brasil, um país que, no relato, era habitualmente posto como filho de Portugal.

Cabe recordar que, para a intelectualidade portuguesa de então, o momento das descobertas teria coincidido exatamente com a ocasião que afastou Portugal do continente europeu. Foram as navegações que retiraram portugueses de seu solo, deixaram o território - até certo ponto - a descoberto, distanciaram o mundo lusitano da Europa, quando o lançaram ao mar. Tal opção pelo oceano trouxera conseqüências no plano material e no plano simbólico. Portugal, precocemente centralizado, definia sua identidade basicamente em função do encontro com outros povos e com outras culturas d'alémmar. Portugal, pela sua própria trajetória nacional, trazia a marca da miscigenação já intrínseca como referência e como constituição coletiva. Sendo assim, não poderia ser a raça o pólo principal para compor a identidade do país. A idéia de uma vocação portuguesa para o mar poderia ser tomada como a grande alternativa, a firmar uma suposta essência da caracterização do país e de seu povo. Tratava-se, então, de firmar e projetar uma identidade de cariz transnacional. Tal especificidade, entretanto, não teria sido historicamente suficiente para entoar o imaginário moderno de estado nacional. Faltava a Portugal homogeneidade cultural interna. Faltava a Portugal consonância com os níveis de cultura dos demais países europeus. Faltava a Portugal demarcar, verdadeiramente, os pilares de sua identidade como país. Portugal assumia simultaneamente sua vocação universalista com a preservação de alguma cultura de província. A preocupação com a tônica civilizatória não parecia suficiente, aos olhos da Europa da época, para criar códigos efetivamente homogêneos no território nacional. A convivência com a diversidade passava a 
ser então entoada e mitificada, como se houvesse nisso projeto, como se houvesse nisso projeção consciente. Os mais ilustres literatos e intérpretes do romantismo português - particularmente na primeira geração romântica-defendiam, com veemência, que se aportuguesasse Portugal. Reforçava-se, por intenções e por gestos, a metáfora do destino, do fado português e, com ele, da saudade: sentimento que imbrica a tristeza do passado com a projeção de um futuro imaginado que, em alguma medida, ainda que pela trilha da mobilização da lembrança, retomará o tempo irremediavelmente perdido...

\section{A G eração de 70 e novasinterpretações de nação, de Portugal e de Brasil}

A chamada Geração de 70 constituiu o grupo-geração que, no último quartel do século XIX, propugnou como idéia central a necessidade de desenvolvimento da cultura portuguesa, particularmente mediante sua necessária integração à cultura européia. Faziam parte dessa geração intelectuais, escritores, historiadores, críticos da cultura - todos educadores, em um sentido mais amplo. Pretendia-se, pela formação da opinião pública consciente, consolidar um espírito público esclarecido, iluminista, promissor de novos futuros. A Geração de 70 tem como marco de fundação a célebre polêmica entre António Feliciano de Castilho e Antero de Quental, e a carta intitulada Bom senso e bom gosto passaria a ser compreendida como o primeiro manifesto daquela geração, em 1865.

Entre 1871 e 1872 aconteceriam as Conferências na sala do Casino Lisbonense. Pensava-se que, através das então intituladas Conferências do Casino, poderse-ia criar um espaço privilegiado para refletir e debater as grandes questões que interpelavam a jovem geração da intelectualidade portuguesa na altura. Na mesma época, Eça de Queiroz e Ramalho Ortigão publicavam textos periódicos, de crítica social, política e literária. Eram As farpas, portanto, bem como as Conferências do Casino, destinadas a uma dada formação do "gosto" - e talvez até do que se supusesse ser o "bom-senso" -, tendo em vista conscientizar a opinião pública leitora para a necessidade de europeizar Portugal. Se as Conferências do Casino colocavam-se à época como agremiação intelectual destinada a veicular elementos da política cultural do que se desejava tornar os novos tempos, As farpas, ao contrário, voltavam-se para a descrição satírica de tudo o que pudesse haver de pitoresco, de galhofa, de pilhéria naquela realidade de nação em atraso - 0 Portugal da época. A crônica dos costumes e do ambiente político e social pretendiam, no dizer de João Gaspar Simões, "farpear as mazelas políticas, sociais, culturais, artísticas, literárias, morais do País" (Simões, s/d, p. 67).

Os inúmeros volumes que posteriormente agregariam o conjunto d'As farpas podem ser tomados como se fossem um grande painel português da segunda metade do século XIX: combinando pequenos detalhes do cotidiano com crítica dos comportamentos, comentários sobre a política em seus vícios e virtudes; imagens que documentariam, enfim, a vida nacional da época, naquilo que ela trazia de glorioso, mas, sobretudo, nos traços que continha de ridículo. O conjunto d'As farpas é, pois, extremamente significativo para retratar as circunstâncias de Portugal do final de século: circunstâncias de vida urbana, mas também do universo rural e das aldeias, circunstâncias de pensamentos e de sensibilidades, de razão e de emotividade - portanto, sinais dos estados mentais de alguma sociedade portuguesa de então. ${ }^{1}$

Pretendendo relatar "pequeninas sensibilidades, pequeninamente contadas por pequeninas vozes" (Queiroz, 1987a, p. 28), Eça de Queiroz, em junho de

${ }^{1}$ Ramalho Ortigão, na primeira edição que agrupava os diferentes fascículos mensais d'As farpas, dirá que "a multiplicidade dos pontos de vista, constituindo a feição característica desta obra, é a dupla origem do que ela tem de especial e do que tem de indigente. $\mathrm{O}$ espírito de diletantismo, de que procedem As farpas, tocando por uma invencível e talvez mórbida curiosidade em todos os fatos da ciência e da arte, em todos os fenômenos da natureza e em todos os atos da humanidade, dispersa o poder de especialização, desconcentra a vontade intelectual, enfraquece as faculdades de análise rigorosa e inabilita para os longos e exclusivos processos de estudo experimental sem os quais é impossível chegar à resolução definitiva de qualquer problema. Por outro lado, comunicando-nos uma espécie de voluptuosidade de colecionador, semelhante à da bricabracomania, e consolando incessantemente o nosso espírito da ruína de cada esperança desmoronada pelo advento de uma nova esperança nascente, pondo no mesmo pé de importância psicológica um discurso da co- 
1871, dizia ter a intenção de fazer com que As farpas pudessem se constituir como "páginas irônicas, alegres e justas, nascidas no dia em que pudemos descobrir, através da ilusão das aparências, algumas realidades do nosso tempo". (Queiroz, 1987a, p. 19)²

Seja como for, muitas das crônicas d'As farpas traziam - para aquilo que aqui nos interessa - comentários satíricos, irônicos, ou mesmo sarcásticos, bastante reveladores da percepção da intelectualidade portuguesa do último quartel do século XIX sobre a situação político-social do Brasil, e, muito particularmente, sobre os brasileiros. Procuraremos, neste específico tópico, identificar algumas das marcas que compunham esse modo português de retratar e avaliar o Brasil de cem anos atrás; certas projeções, alguma utopia de futuro, muita necessidade de demarcação das diferenças, que vinha, por vezes, implícita na rejeição.

O Brasil deixara de ser, de Portugal, o filho dileto. É natural que os portugueses comentassem sobre as es-

roa e uma cantiga da rua, um projeto de lei e uma página de romance, um ministério e um bibelot, o diletantismo atua no caráter emancipado de muitas superstições, de muitas subserviências, de muitas hipocrisias, e colocando o coração, por uma espécie de egoísmo artístico e benéfico, ao abrigo das corrosivas e deprimentes paixões de seita e de partido. Sobre a índole literária o diletantismo determina o livre e desinteressado amor da realidade, expressa não pelas acadêmicas linhas gerais mas pelo traço particular e característico; leva à ironia como sendo a mais delicada e palpitante forma de verdade; e induz a considerar a frase escrita como o objeto de um culto destinado a converter numa consolação de arte, vidente e festival, a pitoresca imagem do atormentado, do dolorido, do efêmero pensamento humano. O leitor apreciará até que ponto se poderão contrapesar na sua estima essas qualidades e esses defeitos fundamentais inerentes à natureza desta obra" (Ortigão, 1986, p. 1-3).

${ }^{2}$ Eça de Queiroz, ao definir a iniciativa d'As farpas, dava a definição pela sua negatividade: "Pobres Farpas! Decerto que elas não são a coluna de fogo, nem as doze tábuas da lei nem a grande voz de deserto! - Enfeitadas e coloridas na sua porção de bandarilhas, aguçadas e incisivas na sua porção de ferro, ágeis e laboriosas como abelhas, elas são sobretudo e antes de tudo 96 páginas impressas na Tipografia Universal, sem grandes erros de gramática e sem grandes verdades de filosofia, estalando de riso por todas as entrelinhas, mesmo quando franzem a testa-e contentando-se com serem alegremente recebidas, pela manhã, à hora do correio e do almoço, por alguns espíritos simpáticos e por algumas brancas mãos" (Queiroz, 1987, p. 86). tratégias de independência efetiva de um país com dimensões de continente - tal como percebiam os que lá ficavam. O português que viera para o Brasil tornarase, por sua vez, uma realidade à parte. Separara-se de seus compatriotas. Falava a língua com outra entonação. Mudara o ritmo de seu tempo, de suas vontades e até mesmo de sua vida. Sendo assim, o português que para cá viera deixara a saudade nos que ficavam; mais do que isso, deixava uma melancolia e um dado ressentimento pelo abandono. Mas o português emigrante representava, substancialmente, a fuga de uma realidade em sofrimento. Emigrar, para Eça de Queiroz, era o "transbordar" de uma população que sobra: "não é o espírito de atividade e de expansão que leva para longe os nossos colonos, como leva os ingleses à Austrália e à Índia; mas a miséria que instiga a procurar em outras terras o pão que falta na nossa" (Queiroz, 1987b, p. 27).

O privilégio do Brasil como local para onde caminhava a emigração fazia com que houvesse um repensar sobre a própria condição de pátria. Portugal seria mesmo uma "Pátria"? Ou seria meramente um sítio; um local? Nos termos de Eça, a idéia de sítio - pela ausência de outra que melhor se adequasse - servia de consolo: "um sítio verdadeiramente é o que temos: isto é - uma língua de terra onde construímos as nossas casas e plantamos os nossos trigos. O nosso sítio é Portugal. Não é propriamente uma nação, é um sítio. Já não achamos mau!" (Queiroz, 1987b, p. 36). A prática da emigração conduzia, contudo, a que um novo sítio se impusesse como local a ser habitado; e, portanto, como outra pátria e nação possível. O Brasil, nessa órbita, tornava-se, paulatina e progressivamente, realidade alternativa, a ser vivida e povoada; uma realidade irrefutavelmente outra. Identificar os sinais da mudança nos corações e nas mentalidades exigiria habilidade pedagógica e astúcia analítica. Decifrar o Brasil era, assim, uma tarefa compreendida na pauta da intelectualidade portuguesa. O tom satírico e a ironia enviada por "farpas" auxiliavam o empreendimento da crítica.

Comentário freqüente d'As farpas de Ramalho Ortigão remetia exatamente à ferina crítica contra os usos da língua portuguesa encontrados na expressão coloquial e mesmo na língua escrita no Brasil. Eram criticados, por exemplo, muitos dos vocábulos aqui utiliza- 
dos, e que não tinham correspondência em Portugal, muitas vezes pelo fato de derivarem do guarani. Os portugueses - diziam As farpas - sentiam-se "esbofeteados" por ver sua língua "desfeiteada", em virtude da verbalização corrente de um estilo que feria o pensamento, comprometia os sentidos e violava as origens da linguagem e as próprias idéias por ela transmitidas:

Vocábulos daqueles não se depositam num dicionário respeitável, atiram-se para uma escarradeira. Os senhores brasileiros tenham a bondade de falar - para a rua, ou nos seus lenços! E o governo, se tem dignidade, deve pelos seus agentes diplomáticos - pôr cobro àquele extravasamento do brasileiro - sobre o português de Camões. Os senhores do Brasil que dêem uma direção à sua linguagem - de modo que não venha cair como um enxurro sobre os nossos dicionários que passam. Em último caso que a canalizem! E assim o brasileiro que tiver a expelir um período eloqüente ou uma frase sublime, já se não aproxima da nossa gramática - dirige-se logo à sarjeta! (Ortigão, 1992b, p. 180)

O Brasil que aparecia n'As farpas era explicitamente o país que jamais conseguira converter a exuberância de seus recursos naturais em gêneros capazes de alimentar seus habitantes. Com um território assemelhado a um continente, parecia aos portugueses completamente absurda a importação de enormes proporções de substâncias alimentícias, fundamentalmente em se considerando que a ex-colônia portuguesa teria uma natural vocação agrícola, que não aproveitara. O Brasil também carecia de meios de transportes e de comunicações, particularmente nas regiões dos sertões, do interior do "país das florestas" (Ortigão, 1992a, p. 49). Além da falta de indústrias, haveria, ainda, uma dimensão de desleixo e de indolência no caráter nacional do brasileiro, cujas propensões não eram exatamente voltadas para o trabalho.

Alguns artigos n'As farpas versavam exatamente sobre a antipatia mútua e natural entre os dois países que, outrora, estiveram nas condições justapostas, um de metrópole e outro de colônia. A antipatia era, pois, uma decorrência natural do histórico de dominação. Diz um artigo - analisando exatamente as relações entre a colonização portuguesa e a dizimação dos indígenas brasileiros - que "os velhos povos conquistadores pergun- tam a si mesmos muitas vezes se não foram eles próprios os que primeiro ensinaram nos países conquistados a violar impunemente o direito" (Ortigão, 1992a, p. 77). Nesse sentido, a prática da opressão existente nos países colonizados poderia ser consequiência da ação predatória dos colonizadores. O raciocínio posto era esse. Mas o articulista pretendia debater a hipótese. Os povos coloniais teriam sido ensinados a agir pela violação dos direitos fundamentais da humanidade? Seria por causa disso que os nativos das colônias tinham o hábito de recusar a herança dos colonizadores? Para responder a tal indagação, especificamente pensando o caso brasileiro, coloca-se o tema na agenda da época:

Que mal fizemos nós ao brasileiro? Nenhum. Demoslhe a vida histórica, demos-lhe os costumes dos nossos pais, a civilização herdada de nossos antepassados, a língua dos nossos poetas. Estamos-lhe dando ainda em cada ano os mais fortes elementos que constituem o progresso - o braço e a inteligência dos nossos filhos mais fortes e mais robustos, o melhor, o mais vermelho, o mais rico do nosso sangue. Nós ficamos abatidos, prostrados, anêmicos. Os mais valentes homens de Portugal, os alentados, os sadios, os diligentes, os pacíficos, os dedicados homens do Norte, os mais aptos para regenerarem pela família a enfraquecida raça portuguesa, para fertilizarem o solo, para cultivarem o estudo, para enobrecerem as idéias, esses homens emigram para o Brasil. Onde está a nossa forte mocidade montanhesa, transmontana e minhota? No Brasil. Onde estão os nossos mais empreendentes industriais, os nossos mais hábeis mercadores, os nossos mais ricos negociantes, os nossos capitalistas, os nossos banqueiros, os nossos proprietários, os nossos trabalhadores, os nossos soldados? No Brasil. Eis o mal que fizemos aos brasileiros. (Ortigão, 1992a, p. 78)

Contudo - reconhece o texto - "o brasileiro paganos [com a rejeição] a dívida do índio" (Ortigão, 1992a, p. 79). E o que é pior: eram os portugueses que viviam no Brasil quem padecia mais diretamente "a expiação providencial e tremenda do antigo conquistador" (Ortigão, 1992a, p. 79); como se ao Brasil competisse historicamente punir os considerados herdeiros das responsabilidades por um passado perverso. Os portugueses do Brasil tornavam-se, assim, paulatinamente, os culpados mais visíveis pela dizimação de povos opera- 
da durante a colonização. É verdade que não se tratava de uma culpa direta. Mas, de qualquer maneira, tratavase de uma culpabilidade herdada, com olhos postos no passado (Martins, 2000).

De acordo com Ramalho Ortigão, o Brasil fora uma conquista que desmoralizou a antiga metrópole portuguesa, já que, enquanto foi colônia, levou Portugal à miséria, e, como país independente, continuou fazendo o mesmo, pelo efeito produzido - ainda que indiretamente - com a "sangria" da emigração. Na imagem projetada do Brasil, a natureza era intrépida e indomável, e, contrariando o que o tom civilizatório recomendaria, era esse poder inextricável do ambiente natural que dominava e subjugava um homem que, sendo assim, relutaria em combater as tentações de um meio "enervante e mórbido, que penetra-o, traspassa-o, prosta-o, inabilita-o inteiramente para a resistência e para a luta" (Ortigão, 1992a, p. 83). Isso apenas confirmaria a asserção de alguém que, sobre o Brasil, teria escrito que "em parte alguma se encontra um tão doloroso contraste entre a grandeza do mundo externo e a pequenez do mundo interior" (Buckle apud Ortigão, 1992a, p. 84).

Ramalho Ortigão procurava convencer seus leitores de que o Brasil não possuía civilização própria, já que não tinha tradição artística, não tinha literatura nacional, nem filosofia, nem poesia, nem riqueza - e a riqueza acumulada não era repartida, mas absolutamente concentrada nas mãos de uns poucos capitalistas cujos empreendimentos em nada revertiam para o povo. A revolta contra a perseguição que dizia existir no Brasil contra colonos portugueses do Pará é encerrada pela simples alegação de que o Brasil nada tivera de seu, nem antes e nem depois dos portugueses, além do próprio português:

Como cada uma destas manifestações da civilização humana lhe não é levada senão em amostra pelos colonizadores do seu litoral, imagina o Brasil que são os seus colonizadores que lhe roubam a ele aquilo que os seus colonizadores possuem e que ele não soube grangear. Mas ponderai bem a vossa cegueira! Considerai o que vos disse Buckle! Se os vossos colonizadores vos largassem a mão com que vos seguram, vós recuaríeis para o selvagem, retrogradaríeis indefinidamente na cadeia dos seres, até reimergirdes no gentio. Sabes, ó Brasil, o que é para ti o colono que tu espancas, que tu insultas, que tu persegues? Sabes o que é o colono? O colono é o médico que te cura a hidropisia, a escrófula e a febre evaporada dos teus charcos e dos teus rios pútridos. O colono é o mestre que te ensina a soletrar os livros que encerram os tesouros do espírito humano, os segredos do universo. O colono é o teu músico, o teu poeta, o teu sábio, o teu agricultor, o teu industrial, o teu banqueiro. O colono é a tua arte, a tua religião, o teu Deus. Finalmente, o colono é o teu imperador. O colono és tu mesmo. (Ortigão, 1992a, p. 84)

\section{0 português de Portugal, o portuguêsda colônia e o modo de ser do Brasil independente}

O emigrado português, colono no Brasil, não possuía, naquele último quartel do século XIX, nem os direitos dos nacionais, nem os privilégios dos estrangeiros outros. Ao chegar ao Brasil, em geral, aquele jovem engajado - como se costumava dizer - trazia em si o vigor da mocidade e os hábitos ativos das províncias do Norte de Portugal, muito particularmente do Minho e de Trás-os-Montes. Nos primeiros tempos, o emigrado, que se tornara imigrante em nossa terra, via-se às voltas com o pagamento de dívidas que contraíra: fosse o preço da passagem, remédios, passaporte, moradia etc. Quando assumia algum trabalho na lavoura, e passava a trabalhar geralmente para algum fazendeiro, o imigrante era, frequientemente, destratado, em virtude dos hábitos contraídos pelos senhores das terras na lida com os escravos. Além disso, como, por vezes, o fazendeiro que o contratara o havia auxiliado no pagamento da dívida que trouxera ao chegar, no princípio, o colono português trabalhava fundamentalmente para pagar essa dívida transferida, que agora ele tinha para com seu patrão.

Ele, com a sua inteligência e a sua atividade, é, portanto, desde então, uma coisa que está pertencendo a outrem. Mete pela primeira vez a sua enxada na terra do exílio com a amargurada consciência de quem já não trabalha nem tão cedo tornará mais a trabalhar para si. Neste momento ou se revolta e é um criminoso, ou se submete e é um escravo. A maior parte desses desgraçados rapazes humilham-se no desalento e na desgraça. Então a nostalgia vem. Como todos os montanheses, os transmontanos e os minhotos têm o sentimento instintivo da pátria penetrante e profundo. O estranho aspecto portentoso da grande natureza equatorial trespassa essas inteli- 
gências estreitas e humildes de uma melancolia devoradora. A natureza inanimada e a natureza viva têm para eles aspectos novos e fantásticos que lhes põem o passado, a família e a pátria nas perspectivas longínquas e nublosas dos sonhos. (Queiroz, 1992a, p. 57)

A permanência em tal situação acabava por confluir em uma legião de deserdados, de relegados, de miseráveis, cada vez distribuída em maior número na excolônia portuguesa. O Brasil que o português emigrado encontrava era um país onde a coligação de fazendeiros era a máxima expressão da lei. N'As farpas de Ramalho Ortigão, com a lógica escravista predominando, o Brasil não conhecia a idéia de direitos. Assim, o imigrante português recém-chegado aliava à tristeza, à saudade $\mathrm{e}$ à estranheza de costumes, todas as dificuldades materiais que o indivíduo não-escravo e não-proprietário mantinha no Brasil daquele último quartel do século XIX. Por absoluta escassez de alternativas, os imigrantes passavam a viver em cortiços, "juntos, aglomerados como gado, em uma espécie de casas de malta ou de albergarias" (Ortigão, 1992a, p. 61). O cortiço seria, assim, o retrato mais cru e mais cruel da decadência. $\mathrm{O}$ português no Brasil, não tendo qualquer direito, era quase considerado um intruso qualquer:

Caso extraordinário e verdadeiramente inexplicável: até hoje a única oposição à emigração de portugueses para o Brasil tem sido feita unicamente - pelo Brasil! Nunca lho agradeceremos com suficiente gratidão. Parece que é ele que tem estado constantemente querendo, pelo que diz respeito às colônias, colonizar-nos a nós antes de se colonizar a si mesmo. O Brasil tem denotado, sempre pela sua política, pela sua legislação, pela mesma arte, pela sua literatura, pela sua opinião pública e pela sua imprensa, que ele tem dos emigrados esta compreensão fabulosamente estranha: que quem os perde não é quem os dá, mas quem os recebe. Na análise singelamente gramatical dos elementos da sua prosperidade, a América brasileira não tem sabido achar - o agente. (Ortigão, 1992a, p. 63)

Carente quanto ao desenvolvimento científico, não havia em solo brasileiro suficientes publicações nem mesmo no domínio dos livros didáticos, até porque a proporção de crianças na escola era irrisória. Se a estatística oficial continha uma proporção de um habitante leitor para sessenta e oito, isso ocorria - conforme cons- tava n'As Farpas - apenas porque se deixavam de computar os escravos.

Mesmo assim - reconhecia Ramalho Ortigão - o Brasil teria ainda alguns poucos elos de ligação que irremediavelmente o imbricavam a Portugal. Um desses elos era o do mercado livreiro. Afinal, de Portugal, viera a língua. Por sua vez, não havia produção literária brasileira suficiente para satisfazer o próprio mercado leitor do Brasil. O português nisso não disfarça a própria vaidade de colonizador: "o Brasil é um sertão povoado de portugueses; portanto, [...] é sobretudo guloso das nossas obras. O Brasil aprende a sentir pelos nossos romances - como aprende a contar pelas nossas aritméticas" (Ortigão, 1992c, p. 89). Se há evidentemente improcedência na idéia de "aprender a sentir" pela leitura dos romances portugueses, parece bastante provável a apropriação feita das obras didáticas editadas em Portugal por parte do mercado de livros no Brasil. Segundo o mesmo artigo d'As farpas, havia, inclusive, um cálculo já conhecido pelos escritores portugueses. Publicava-se um livro; a tiragem supunha, geralmente, 1.000 exemplares para Portugal, mais 2.000 exemplares para venda no Brasil. Tal cômputo era de conhecimento público, assim como se dizia também que ocorriam com muita freqüência reimpressões de livros portugueses no Brasil, por iniciativa de editoras brasileiras, que passavam a explorar o tex to comercializado, sem qualquer contato ou garantia de direitos de autor: "no Brasil, um ladrão qualquer toma um exemplar desse livro, reimprime-o lá, vende-o lá, esgota-o lá, explora-o lá. De modo que o Brasil compra ao ladrão brasileiro os 2.000 exemplares brasileiros - em vez de comprar exemplares portugueses ao escritor português" (Ortigão, 1992c, p. 89).

$\mathrm{Na}$ verdade, havia - pelo que nos relatam As farpas - uma verdadeira querela pelo fato de os editores brasileiros comercializarem verdadeiros plágios ou mesmo reproduções não-autorizadas e, portanto, ilícitas de obras portuguesas editadas, a princípio, em Portugal. Tais usos ilegítimos dos recursos da tipografia conduziam a um escandaloso roubo da propriedade literária; o que era denunciado, inclusive, apelando para a autoridade moral do Imperador do Brasil.

Tendo visto aqui um imperador tão interessado nas coisas do espírito, dizemo-lhe francamente [...] Por quê, senhor? 
Dar-se-á acaso que o roubo esteja tanto nos costumes do país e nas profundidades do seu temperamento que Vossa Majestade, com todo o seu poder imperial - não se atreva a dar-lhe batalha? [...] Aqui diz-se que Vossa Majestade não quer tomar a iniciativa desta questão por ela pertencer especificamente à competência do ministro. Mas então - a quem se quer enganar, como dizia o barbeiro Fígaro? Porque todos sabem que Vossa Majestade possui, no Brasil, um poder pessoal ilimitado, despótico, no sentido filosófico da palavra, e seus ministros são apenas assinaturas de chancela [...]. Alguns jornais portugueses ponderam que o Brasil nunca cederá nessa questão porque tem medo de perder. [...] Seria um fato imprevisto na história - uma nação declarando, pelos seus representantes oficiais e pelos seus tratados - que não pode deixar de roubar para viver - e que a sua fortuna pública conta, desde o começo do ano econômico, com o que lhe produzem os seus ladrões.

(Ortigão, 1992c, p. 92)

Eça de Queiroz comenta, em uma de suas Cartas da Inglaterra, artigo do Times referente à situação do Brasil na altura. Diz ele que, como sempre, o correspondente destacava as riquezas naturais, a vastidão territorial, o exotismo dos costumes nativos, o canto das aves raras... Porém, Eça destaca o comentário conclusivo do referido artigo, o qual sublinhava - a propósito do caso brasileiro - a magreza dos resultados diante da grandeza dos potenciais. Estendendo o comentário para a América Latina de maneira mais geral, o texto descrito do Times teria salientado a má combinação entre perniciosa indolência, insensata arrogância e "muita exagerada vaidade" (Queiroz, s/d-b, p. 593). Eça estranha a análise efetuada pelo artigo em causa, quando este singulariza a situação do Brasil diante dos países da América espanhola, acentuando nossas potenciais virtudes: para o Times, embora já independente, o Brasil teria mantido uma dada nacionalidade portuguesa, sendo "semi-europeu de espírito" (Queiroz, s/d-b, p. 594). Eça discorda do parecer ali exarado, quanto a esse suposto "sentir português" (Queiroz, s/d-b, p. 594) preservado em terras brasileiras. Estranha também que o artigo aproxime Portugal dos chamados povos civilizados. Portugal era um "sítio" que desprezaria sua própria inserção na Europa, sendo, como contrapartida, também desdenhado por ela. Haveria, entre Portugal e Europa, uma fronteira que demarcava lugares e feições distintos e peculiares. A carência educacional, o atraso científico teriam conduzido Portugal ao merecido desprezo dos europeus. Portugal estaria afastado da Europa, talvez por sua obsessão em aportuguesar-se. Nos termos de Eça:

Somos o que se pode dizer um povo de bem, um povo boa pessoa. E a nação vista de fora e de longe, tem aquele ar honesto de uma pacata casa de província, silenciosa e caiada, onde se pressente uma família comedida, temente a Deus, de bem com o regedor, e com as economias dentro de uma meia... a Europa reconhece isto: e todavia olha para nós com um desdém manifesto. Por quê? Porque nos considera uma nação de medíocres: digamos francamente a dura palavra - porque nos considera uma raça de estúpidos. Este mesmo Times, este oráculo augusto, já escreveu que Portugal era, intelectualmente, tão caduco, tão casmurro, tão fóssil, que se tornara um país bom para lhe passar muito ao largo e atirar-lhe pedras (textual). O Daily Telegraph já discutiu em artigo de fundo este problema: se seria possível sondar a espessura da ignorância lusitana! Tais observações, além de descorteses, são decerto perversas. Mas a verdade é que numa época tão intelectual, tão crítica, tão científica como a nossa, não se ganha a admiração universal, ou se seja nação ou indivíduo, só com ter propósito nas ruas, pagar lealmente ao padeiro, e obedecer, de fronte curva, aos editais do governo civil. São qualidades excelentes, mas insuficientes. Requer-se mais: requer-se a forte cultura, a fecunda elevação de espírito, a fina educação do gosto, a base científica e a ponta de ideal que em França, em Inglaterra, na Alemanha, inspiram na ordem intelectual a triunfante marcha para a frente [...] Bom Deus, não! Eu não reclamo que o país escreva livros, ou que faça arte: contentar-me-ia que lesse os livros que já estão escritos, e que se interessasse pelas artes que já estão criadas. A sua esterilidade me assusta menos que o seu indiferentismo. O doloroso espetáculo é vê-lo jazer no marasmo, sem vida intelectual, alheio a toda a idéia nova, hostil a toda a originalidade, crasso e mazorro, amuado ao seu canto, com os pés ao sol, o cigarro nos dedos e a boca às moscas... É isto o que punge. (Queiroz, s/d-b, p. 595-596)

Retornando ao artigo do Times, Eça observa que, pela imprensa internacional, o Brasil era visto como a mais promissora das nações da América do Sul, embora as dimensões continentais daquela ex-colônia portuguesa ainda não fossem exploradas como deveriam para bem administrar sua população e povoar, de maneira melhor 
distribuída, seu vastíssimo território. Mas, de acordo com a interpretação do artigo do Times, como os brasileiros não eram muito afeitos ao trabalho, o pouco que conseguiam cultivar o faziam pelo uso quer da mão-de-obra escrava, quer dos esforços do imigrante. Isso conduzia à suposição de que, caso os brasileiros se revelassem ineptos para gerir o tesouro que tinham na terra, haveria um explícito e notório interesse europeu em dela se apropriar; nos termos do seguinte raciocínio: "se os possuidores atuais são incapazes de os fazer valer e produzir, para maior felicidade do homem, deverão então entregálos a mãos mais fortes e mais hábeis. É o sistema de expropriação por utilidade de civilização", a qual, à luz da crítica de Eça, seria a "teoria favorita da Inglaterra e de todas as nações de rapina...” (Queiroz, s/d-b, p. 598).

Em carta escrita de Paris para Eduardo Prado, Eça de Queiroz (sob o álibi de Fradique Mendes) atende, com alguma relutância, a uma suposta solicitação de seu interlocutor brasileiro, que lhe pedia uma opinião sobre o Brasil. Eça é bastante cauteloso: não falava ali com a imprensa; mas com um amigo. Mesmo assim, não deixa de emitir sua impressão de que "os brasileiros, desde o imperador ao trabalhador, andam a desfazer e, portanto, a estragar o Brasil" (Queiroz, s/d-a, p. 245). A idéia que permeava a análise tinha por referente a estereotipada visão de uma terra essencialmente dotada de promessas de futuro, "em pleno viço, com tudo por criar no seu solo esplêndido" (Queiroz, s/d-a, p. 245). Com toda essa riqueza em suas mãos, caberia aos brasileiros a fundação de uma civilização profundamente especial, como se fosse um artista modelando o barro que tem à sua frente, podendo "fazer dele, à vontade, uma vasilha ou um deus. Não desejo ser irrespeitoso, caro Prado, mas tenho a impressão de que o Brasil se decidiu pela vasilha" (Queiroz, s/d-a, p. 245).

A crítica de Eça - segundo ele próprio - recai sobre o Brasil que ele observara ao longe, e que se havia nítida e voluntariamente se distanciado de sua genuína espontaneidade, retocado agora de artifícios, "feito com velhos pedaços da Europa, levados pelo paquete e arrumados à pressa, como panos de feira, entre uma natureza incongênere, que lhe faz ressaltar mais o bolor e as nódoas" (Queiroz, s/d-a, p. 246). faltava solidez ao caráter nacional do brasileiro. Faltava autenticidade àquela cultura, desenhada e deturpada pelo efeito da importação. Costumes abandonados; rituais desdenhados; busca desesperada de cópia dos padrões europeus. O Brasil deixara - é certo - de ser colônia portuguesa. Contudo, o espírito colonial permanecera cristalizado nas representações simbólicas. Havia um nítido processo de desnacionalização do Brasil paradoxalmente levado a termo pelos seus ditos doutores que, em tudo, amoldavam-se à moda da França ou às idéias da Inglaterra, ou ao falseamento de doutrinas germânicas. Tendo procurado o novo no Brasil - diz Eça - "só encontrei o velho, o que já é velho há cem anos na nossa Europa" (Queiroz, s/d-a, p. 251). Do Brasil autêntico, nada haveria restado: nem mesmo os brasileiros; substituídos que haviam sido pelos doutores - "que são entidades diferentes" (Queiroz, s/d-a, p. 245). Nos termos da carta de Eça:

Em breve o Brasil ficou coberto de instituições alheias, quase contrárias à sua índole e ao seu destino, traduzidas à pressa de velhos compêndios franceses. [...] Os velhos e simples costumes foram abandonados com desdém; cada homem procurou para a sua cabeça uma coroa de barão, e, com 47 graus de calor à sombra, as senhoras começaram a derreter dentro dos gorgorões e dos veludos ricos. Já nas casas não havia uma honesta cadeira de palhinha [...], todo o pesadume de decoração estofada com que Paris e Londres se defendem da neve, e onde triunfa o micróbio. Imediatamente alastraram as doenças das velhas civilizações, as tuberculoses, as infecções, as dispepsias, as nevroses, toda uma surda deterioração da raça. E o Brasil radiante - porque se ia tornando tão enfezado como a Europa, que tem três mil anos de excessos, três mil anos de céus e de revoluções! (Queiroz, s/d-a, p. 248-249)

Eça, de algum modo, ressentia-se do que acreditava ser a perda de um suposto "Brasil autêntico", original, quase um estado de natureza que - na tentativa de se assemelhar à Europa - se fora irremediavelmente; indo, com ele, também as suas características. É curioso que o mesmo escritor, tão enfaticamente defensor da bandeira da europeização de Portugal, explicitasse seu pesar quanto à impregnação no Brasil de uma Europa não portuguesa... Em suas palavras: "a nação inteira se doutorou. Do Norte ao Sul do Brasil, 
não encontrei senão doutores! [...] Uma tão desproporcionada legião de doutores envolve todo o Brasil numa atmosfera de doutorice" (Queiroz, s/d-a, p. 249-250). O caráter essencial da doutorice seria, aos olhos do escritor, o desejo de organizar e de administrar o mundo mediante orientações livrescas. Esse feitio contaminava, na altura, o pensamento sobre o Brasil por parte dos próprios brasileiros, incapazes que eram de identificar as verdadeiras especificidades e particularidades de seu país.

No que toca, portanto, às interpretações de Brasil, pode-se dizer que a preocupação mais imediata dos protagonistas da Geração de 70, e, mais particularmente, de Eça de Queiroz, derivava do pressuposto de que estaria em curso um processo de "desnacionalização do Brasil”, de morte de sua espontânea, intrínseca e tacitamente eterna "originalidade nativa", já que tanto doutrinas, quanto moda ou literatura, tudo no Brasil soava ao estrangeiro: Inglaterra, França e até Alemanha. Era como se o que havia de genuinamente brasileiro houvesse sido tapado por tapete construído pelos remendos da cultura e dos costumes europeus, o que, evidentemente, descaracterizava as especificidades intrínsecas ao solo brasileiro. O Brasil estaria latejando, escondido sob véus que lhe seriam absolutamente alheios e artificiais. Urgia que os brasileiros pudessem desembaraçar seu país desse "tapete europeu que o recobre, o desfeia, o sufoca. A chance está em que o novo imperador ou rei seja um moço forte, são, de bom parecer, bem brasileiro, que ame a natureza e deteste o livro" (Queiroz, s/d-a, p. 252). Com tais palavras, o escritor parecia conclamar o Brasil - pelas palavras de Fradique Mendes - a permanecer como o último reduto do estado de natureza. Ser brasileiro seria, pois, essencialmente, honrar o que a natureza nos dera como país. Qualquer gesto contrário era tido, por definição, como traição ao nosso caráter nacional. Os males de nosso modelo social e político derivariam dessa traição original, que, no pensamento do escritor, não honrava a inteligência de nossos homens, a beleza de nossas mulheres e, fundamentalmente, a bondade natural de nosso povo...

Ao comentar aspectos da política brasileira, Eça de Queiroz não hesita em ridicularizar o Brasil, basicamente no que dizia respeito à fragilidade historicamente caricatural de suas instituições. Sobre a proclamação de nossa República, por exemplo, dirá o escritor que "sem choque, sem ruído, como cenas pintadas que deslizam, a monarquia, o monarca, o pessoal monárquico, as instituições monárquicas desaparecem - e, ante a vista assombrada, surge uma república, toda completa, apetrechada, já provida de bandeira, de hino, de selos de correios e da bênção do arcebispo de Lacerda. Sem atritos, sem confusão...”(Queiroz, 1979, p. 938). Os funcionários das repartições de Estado continuam a despachar os papéis de rotina: em vez de escreverem "em nome do Imperador", passam a endereçar os papéis ao "Presidente da República". Além disso, teriam sido pouquíssimas as mudanças. Uma revolução pelo alto, que carecera de qualquer modificação no imaginário - nos corações e nas mentes daquelas populações. A partir dali todos seriam republicanos; ainda que, até a véspera, houvessem sido todos monarquistas. Paradoxalmente, a República brasileira - continua o analista - fora gestada por idéias jacobinas das quais se imbuíam bacharéis (formados muitas vezes em Paris ou em Coimbra), ansiosos por realizar um "velho ideal jacobino, já entre nós [em Portugal] desacreditado e um pouco obsoleto, e que no Brasil domina ainda as inteligências tropicalmente entusiásticas e crédulas" (Queiroz, 1979, p. 938).

Não havia então óbice algum à idéia de República - para além dos descontentes proprietários rurais do café, para os quais expressões como unidade nacional, centralização, política e relações exteriores nada diziam, e para quem, aliás, a libertação dos escravos havia sido um forte componente de ruptura da aliança que tinham com a monarquia. O problema não era a República; mas a pessoa do Imperador, o qual, segundo o escritor, não possuía efetivamente a estima de seu povo, posto que não encarnava dele hábitos ou modos de estar no mundo. Eça de Queiroz calcula, ainda, que, àquela altura, dificilmente o Brasil se manteria unido; muito provavelmente - sugere o escritor - cada estado adquiriria a seu tempo sua história própria e independente, e, com isso, por suposto, o Brasil deixaria de ser o Brasil. Essa foi a hipótese acenada pelas "páginas esquecidas" do escritor português talvez mais lido no Brasil... 


\section{0 "brasileiro toma-viagem": estereótipos, tipificaçõese cristalizações}

Como destaca Fernando Catroga, havia no século XIX uma expressão típica para caracterizar os portugueses que regressavam do Brasil para Portugal: eram chamados - com algum caráter jocoso - de "brasileiros torna-viagem". A idéia supunha que o emigrado que regressava à pátria não vinha exatamente para produzir; mas vinha descansar. Havia um certo preconceito contra aqueles que, tendo se aventurado a "fazer a vida" no Brasil, retornavam a Portugal, trazendo não mais a força do seu trabalho e de sua produtividade, mas, essencialmente, seu ócio e os juros do dinheiro que deixaram no Brasil. A esse indivíduo, chamavam-lhe o "brasileiro torna-viagem"; sobre ele, pode ser encontrada toda uma literatura que o tipifica e o simboliza.

O português só chega a denominar-se brasileiro quando não traz para Portugal senão a sua ociosidade e os juros do seu dinheiro, quase nunca os seus capitais. O seu comércio, a sua indústria, a sua influência civilizadora, os poderosos elementos de trabalho de que ele dispunha ficaram no Brasil. Foi lá que o brasileiro deixou o seu negócio entregue à gerência de um associado, a fábrica trespassada ao seu contramestre, a loja ao seu primo caixeiro, a roça a um feitor ou a um mascate enriquecido. [...] Que faz no Brasil o emigrante português? Exerce a temperança e o trabalho, lança os mais sólidos e profundos alicerces à civilização e à felicidade em um país estranho. Que traz ele à pátria? Traz-lhe o dinheiro, a ociosidade, a propensão para gozar - coisas que [...] não foram nunca durante todo o decurso da vida nacional senão os agentes imediatos e fatais da nossa corrupção, da nossa decadência, do rebaixamento profundo da nossa dignidade e da nossa consciência. (Ortigão, 1992a, p.72)

As relações entre Portugal e Brasil, naquele último quartel do século XIX, eram, explicitamente, algo tensas, a tomar como testemunho essas fontes da literatura e da imprensa. Na ausência talvez de um conhecimento mútuo, Portugal falava de um Brasil que não lhe era absolutamente familiar. Tratava-se de um desconhecimento pelo descompasso. O Brasil que pairava nas representações populares - fosse pelo efeito da imprensa, fosse pelas páginas dos manuais escolares - era uma determinada imagem, bastante questionável e inegavelmente ultrapassada, do Brasil colonial, ainda que a Independência houvesse já ocorrido há cerca de cinqüenta anos. Portugal falava, pois, de um Brasil que lhe era desconhecido; e o fazia fundamentalmente mediante estereótipos e projeções subjetivas, pouco esclarecedores para a compreensão do que realmente se havia tornado a ex-colônia - sempre objeto da curiosidade e da preocupação portuguesa.

É bastante provável que o Brasil vivesse exatamente o mesmo desconhecimento, posto que, tanto aqui quanto lá, procurava-se visualizar o presente pela referência dos elos passados. Tal comportamento anacrônico evidentemente gerava incompreensão; e, da incompreensão, o não-reconhecimento da cultura do outro, posto que o momento presente nunca é uma tradução natural, um decalque, e, nem mesmo, um linear desdobramento do que supomos ser o passado. No caso português, tal situação mostrava-se com singular nitidez, mediante a rejeição feita a todos os que, havendo regressado da viagem de emigração, traziam internalizados elementos da cultura brasileira, no que esta tinha de diferente: fosse pelos modos de falar, pelos modos de trajar, ou, fundamentalmente, pelo espectro das referências mentais. $\mathrm{O}$ português do Brasil "se abrasileirara" aos olhos de Portugal; e era como se isso fosse uma traição na origem... Tornara-se uma categoria à parte: "brasileiro torna-viagem”. Para o Brasil, contudo, esse emigrado persistia sendo sempre "o portuga"... O que significa, na prática, que, ao emigrado, não há saída: trata-se sempre de ser o outro de onde se está.

Em texto datado de fevereiro de 1872 e posteriormente publicado em Uma campanha alegre, Eça de Queiroz satiriza o português regressado como o tipo mais popular de caricatura nacional. "Grotesco clássico", fundamentalmente pelos modismos com que desejava demarcar sua distância dos compatriotas, esse português regressado, a quem chamavam de "o brasileiro", trazia consigo um estilo, um modo de ser e de estar no mundo, absolutamente desdenhado e rejeitado em Portugal.

Eça identifica no "brasileiro torna-viagem" o próprio ideal típico feito a propósito para o "riso público". Nos termos do escritor: "o povo supõe-no [...] o herói de todas as histórias universalmente risíveis, o senhor 
de todos os prédios grotescamente sarapintados, o freqüentador de todos os hotéis sujamente lúgubres, o namorado de todas as mulheres gordalhufamente ridículas" (Queiroz, 1987b, p. 72). Grosseiro, barrigudo, arrogante, com chapéus-de-sol e vestimentas exóticas, o brasileiro costumava construir na aldeia sempre a casa que destoava do conjunto; como se quisesse, por gestos e por maneiras, marcar e perpetuar sua diferença galhofeira. Isso fazia com que, fosse nos ditos populares, fosse por anedotas, fosse pela inscrição literária ou mesmo como motivo de ornato industrial para desenhos e enfeites, o português regressado da antiga colônia se prestasse a ser inevitavelmente motivo de pilhérias e comentários sarcásticos. Nas palavras de Eça “o pobre brasileiro, o rico torna-viagem é, hoje, para nós, o grande fornecedor do nosso riso" (Queiroz, 1987b, p. 72).

A seguir, Eça aprofunda a análise mediante a explicitação de sua hipótese - no mínimo ousada e atrevida aos olhos dos contemporâneos - quanto ao que supunha ser a razão das especificidades intrínsecas àquele português retornado, na época nomeado "brasileiro torna-viagem". O que será que diferenciaria tanto esse indivíduo, aos olhos de seus compatriotas portugueses? Por que, afinal, ele adquiria tais características que davam sempre a impressão de um ridículo desejo de distinção? A tese defendida por Eça é, aqui, bastante perspicaz, ainda que algo insolente para farpear os costumes de uma dada interpretação de Portugal daquele final de século. De acordo com o escritor que - ao fim e ao cabo fora, com Antero de Quental, Oliveira Martins e Teófilo Braga, um dos protagonista da Geração de 70, os portugueses que permaneciam na Península riam-se dos que saíram de sua terra e para ela posteriormente regressaram por visualizarem nesses sujeitos algumas peculiaridades de traços e de conduta que teriam sido as suas se a oportunidade os houvesse contemplado. Nesse sentido, o brasileiro torna-viagem - diz Eça - seria "simplesmente a expansão do português” (Queiroz, 1987b, p. 72). Tomando por analogia leis da física de retração e dilatação dos corpos por conta das influências do ambiente, particularmente de aspectos concernentes ao clima e à temperatura, Eça insinua que "os corpos ao calor dilatam, ao frio encolhem" (Queiroz, 1987b, p. 72). A mesma lei - satiriza o autor - poderia ser aplicada aos ho- mens; e aí viria o teor de provocação contido na descrição do "brasileiro torna-viagem" como a dilatação do potencial contido já no português:

O Brasileiro é o português - dilatado pelo calor. O que eles são - expansivamente - nós somo-lo, retraidamente. As qualidades internadas em nós, estão neles florescentes. Onde nós somos à sorrelfa ridiculitos, eles são à larga ridiculões. Os nossos defeitos, aqui sob um clima frio, estão retraídos, não aparecem, ficam por dentro: lá, sob um sol fecundante, abrem-se em grandes evidências grotescas. Sob o céu do Brasil, a bananeira abre-se em fruto e o português rebenta em brasileiro. Eis o formidável princípio! O Brasileiro é o português desabrochado. [...] Que somos nós? Brasileiros que o clima não deixa desabrochar. Sementes a que falta o sol. Em cada um de nós, no fundo, existe, em germe, um brasileiro entaipado, afogado - que, para crescer, brotar em diamantes de peitilho, calos e prédios sarapintados de verde, só necessita embarcar e ir receber o sol dos trópicos. Cada lisboeta, sabeio, traz em si a larva de um brasileiro. Nós aqui vestimos cores escuras, lemos Renan, repetimos Paris, e, no entanto cá dentro, fatal e indestrutível, está aboborando - um brasileiro. Quem o não tem sentido agitar-se, como o feto no seio da mãe? Fitais às vezes uma gravata verde com pintas escarlates? É o Brasileiro a remexer por dentro. Desejais inesperadamente uma boa feijoada comida em mangas de camisa? É o brasileiro. [...] E quereis uma prova? É o verão! É o cruel verão! Então sob a temperatura germinadora - o Brasileiro interior tende a florir, a desabrochar, a alastrar em cachos. [...] Sabeis o que é? É o Brasileiro que tendes dentro na entranha, atraído pelo sol, a querer romper! (Queiroz, 1992 a, p. 73-74)

De alguma maneira, a comparação - embora seja explicitamente dirigida ao português que regressa do Brasil - deixa transparecer consigo, ainda que subrepticiamente, alguma imagem que Portugal tinha do próprio Brasil e dos brasileiros. E não é por acaso. $\mathrm{O}$ brasileiro de verdade - na acepção desses autores - era eminentemente português. Haveria, pois, no efeito do reconhecimento, uma identificação de traços entre o português no Brasil e os descendentes de portugueses que aqui teriam construído uma civilização portuguesa de verão. Troçar do brasileiro era, por suposto - acredita Eça -, identificar nele expressões que seriam alheias aos costumes portugueses. Ora, a argumentação aqui tecida faz confluir 
para a perspectiva de que os portugueses trariam consigo potencialmente os modos de ser e de estar no mundo que o Brasil teria desenvolvido e ampliado em sua cultura. Do contrário, os “torna-viagem" não se teriam tornado como eles... Mesmo assim, Eça reconhece alguma hipocrisia no trato com a ex-colônia, já que, nos usos e nos costumes, havia uma imagem do brasileiro que não se assemelhava àquela versão oficialmente transmitida. Note-se que, embora o artigo seja referido ao "tornaviagem", nesse caso, trata-se mesmo de uma dada leitura do Brasil bastante presente em Portugal do final do século XIX: " por isso tu - que em conversas, entre amigos, no café, és inesgotável a troçar o Brasileiro - no jornal, no discurso ou no sermão, és inexaurível a glorificar o Brasileiro. Em cavaqueira é o macaco; na imprensa é o nosso irmão de além-mar" (Queiroz, 1992a, p. 74-75).

\section{Passadoscem anos, outros 500 ? 0 u apenas 501 ?}

Procurando reconhecer imagens do Brasil a partir de vestígios extraídos de fontes documentais impressas, tanto de cariz didático quanto popular, procurou-se vistoriar algum discurso presente em Portugal do século XIX sobre as idéias de Brasil: representações, mentalidades, símbolos e projeções. Percebe-se que se tratava de uma realidade tanto recusada quanto sublimada. $\mathrm{O}$ Brasil era talvez o outro mais desejado de Portugal. Por outro lado, o suposto criador rejeitava os rumos da criatura. Entendia-se o Brasil como um filho cujo destino fugira da alçada paterna. Um filho desorientado, subversor de valores e de costumes, um filho indisciplinado e rebelde. O que, para os portugueses, talvez fosse mais difícil era exatamente o reconhecimento do Brasil como filho mal-educado; no sentido mais pleno da expressão. Se havia má-criação, não seria em virtude dos males infantis de sua orientação colonizadora? Até que ponto Portugal, portanto, se reconhecia como cúmplice das mazelas brasileiras?

Tomando como referência a hipótese de Boaventura de Souza Santos (1993) quanto à especificidade portuguesa dentre os países do mundo moderno - qual seja, a de sua incapacidade de se diferenciar perante o exterior e de se homogeneizar internamente -, é possível reco- nhecer que o olhar para o Brasil e para as demais colônias tinha a ver com a identificação da necessidade de marcar seu diferencial perante algum exterior. Portugal, em alguma medida, rejeitado pela Europa, agia em relação aos povos que conquistara com um dado desdém, que visava exatamente demarcar, no caso, sua circunscrição européia e, portanto, distinta e superior ao lugar social da sua ex-colônia.

Outra hipótese que nos parece plausível tem a ver com uma certa recorrência a um passado grandioso das navegações e descobertas, como a grande marca que singularizava e destacava o caso português, como verdadeiro fundador dos tempos modernos. Sendo assim, o orgulho português e a afirmação de sua identidade nacional estariam irremediavelmente atados ao passado cosmopolita, ao qual se teria seguido uma longa jornada de indeclinável decadência. Ora, o Brasil, para os portugueses, era exatamente o contrário: uma terra que contava com vastíssimos potenciais de natureza e de território, uma terra em pleno viço de uma juventude promissora; e, portanto, um país rico em virtuais e promissores futuros, os quais Portugal não conseguia visualizar para si. Quanto ao exotismo dos costumes, quanto aos hábitos tropicais, tudo isso assinalava algum ressentimento da perda. O Brasil emancipado tomara rumos que o poderiam, a pouco e pouco, distanciar irremediavelmente do país que o "descobriu". Assim, a emancipação da independência trouxera consigo algum pesar do lado português - o que, no plano das representações mentais, era, aliás, bastante natural, em se tratando, ao fim e ao cabo, da ruptura de um "pacto colonial" (Novais, 1985). Como destaca Laura de Mello e Souza, a visão do paraíso trouxera ao Ocidente o seu outro lado: "na viagem o viajante inventaria e descobre paulatinamente o seu lugar de origem, o lugar de onde procede, e estabelece uma relação especial com a viagem" (Souza, 1993, p. 25). Ora, Portugal - desde a Independência - voltava de uma longa e inesquecível viagem e, ao refletir sobre o que vira, talvez se reconhecesse ocularmente nas paisagens e imagens de vida que, a despeito disso, parecia desejar rejeitar.

Outro aspecto a ser considerado quando se busca apreender os olhares sobre o Brasil presentes no Portugal liberal e monárquico decorria, em larga medida, do 
fenômeno que o século XVIII já chamara de "sangria da emigração". Os portugueses emigravam com muita freqüência. Um dos alvos prediletos para a saída era o Brasil. Evidentemente, isso tinha efeitos para a economia do país e fundamentalmente para o plano do universo simbólico: parecia que a criatura se tornara mais atraente do que aquele que acreditava ser seu criador. Daí talvez também o paradoxo do binômio atração-rejeição que sintomaticamente caracterizava o parecer de Portugal acerca do Brasil.

De alguma maneira, passados outros cem anos, e agora em tom de comemorações de quinhentos anos de encontro entre os povos, o que pareceu haver foi, mais uma vez, um desencontro. Em alguma medida, as relações Portugal e Brasil permanecem onde estavam cem anos atrás. A despeito do avanço dos meios de comunicação, a despeito da própria possibilidade de contato instantâneo, a despeito dos inequívocos esforços por parte das comunidades acadêmicas e editoriais dos dois países e mesmo dos esforços diplomáticos mais diretos, persiste um dado nível de representações cristalizadas e, por vezes, algo estereotipadas, de parte a parte. Portugal, hoje, vive o fenômeno oposto ao da emigração, no caso de suas ex-colônias. O brasileiro é hoje alguém que, ao chegar em Portugal como estrangeiro, talvez seja, mesmo, recebido como estrangeiro de segunda classe. É compreensível que, de algum modo, nos corações e nas mentalidades do homem português, exista um tom saudoso do mistério das navegações e de toda a projeção ali contida quanto à percepção de uma pátria portuguesa expandida como a grande matriz da modernidade ocidental. Sucede que os rumos da colonização imediatamente evidenciaram o fracasso. Portugal, voltado para as terras do além-mar, por sua vez, não atentara para o parco desenvolvimento interno de seu território na Europa. As estratégias para colonizar não foram propriamente aplaudidas por seus naturais herdeiros. No entanto, nem por isso Portugal desfrutou, enquanto metrópole, de níveis significativos da riqueza advinda de sua extração colonial; Portugal não se desenvolveu quanto aos seus níveis internos de prosperidade econômica, no âmbito da sua agricultura, da sua urbanização, nas taxas de alfabetização. Desse modo, o país parecia haver perdido o lugar privilegiado que acreditava possuir na aven- tura da criação dos novos tempos. E o Brasil era o exemplo mais flagrante desse malogro. Se, os portugueses não foram capazes de identificar o quão difícil era para eles criar parâmetros de homogeneidade interna ao seu território, exatamente para criar o efeito da distinção que conferiria prestígio perante os demais povos europeus (Santos, 1993), no caso brasileiro, a despeito da inegável capacidade que a colonização portuguesa demonstrou quanto à preservação da unidade territorial, talvez tenha existido, por parte da antiga metrópole, alguma rejeição quanto à resistência interna no Brasil de hábitos e de costumes que nada tinham de ocidentais, de racionais, de civilizacionais - no que toca ao modelo eurocêntrico de compreender a própria acepção de cultura. A cultura indígena preservou-se na denominação dos espaços, das cidades, por mais que se buscasse renomear o território. A cultura africana trouxe-nos um modo de estar no mundo que não condizia com os padrões de civilidade propugnado pelos compêndios didáticos que muito provavelmente eram recomendados em nossas escolas. O brasileiro, assim, organizou sua circunscrição cultural a partir de matrizes profundamente variadas, que percorrem também os povos imigrantes; os quais freqüentemente traziam outros contributos, apropriados e recriados à moda brasileira. O português, desde logo, reconhece que a formação do Brasil contemporâneo fugia de suas prescrições, de suas orientações, de suas expectativas e de seu desejo. O português talvez reconhecesse, inclusive, em algum modo brasileiro de ser, um talvez Portugal que fugia, progressivamente, de si mesmo. A língua era mutante; os costumes adaptáveis; a cultura assimilava influências difusas e aparentemente contraditórias: e tudo isso convivendo, talvez bem, talvez mal... Sucede que, em escala mais longínqua, também a cultura portuguesa se construíra por sincretismos interculturais. Portugal também era, na origem, multicultural: celta, visigodo, romano, judeu, lusitano-eram diferenciadas as matrizes que impediam que o fator rácico pudesse dar a explicação última da cultura portuguesa. Diferentes vestígios das variadas culturas ainda vigiam em costumes de regiões diferenciadas daquele país - ainda que tão pequeno em seu território europeu. Porém, no Brasil, a desobediência e o caráter multifacetado dos hábitos e das tradições criadas e per- 
petuadas dificultavam a própria compreensão. O Brasil recebia qualquer coisa para, imediatamente, transformála e adaptá-la. Parecia não haver nenhum filtro. Por outro lado, parecia se perder a própria originalidade da coisa recebida. Assim entendiam os portugueses. Tal situação era muito visível. Isso perturbava e, em alguma medida, ainda hoje pode perturbar no exterior a persistência na visibilidade deste país que parece ter por princípio o escancarar de suas misérias...

O fluxo imigratório, atualmente, dirige-se, ao contrário, do Brasil para Portugal. Com a globalização, como projeto transnacional de construção de uma dada cerca mundializada, Portugal se coloca geográfica e simbolicamente como a porta de entrada da Europa. Brasileiros, angolanos, moçambicanos, que para lá emigram, adquirindo, muitas vezes, própria cidadania européia, concorrem a um mercado de trabalho já bastante restrito, com elevadas e progressivas taxas de desemprego, muitas vezes, retirando o lugar dos próprios portugueses. Além disso, no que diz respeito a profissões liberais ou acadêmicas, o preconceito específico contra o ingresso dos brasileiros é uma realidade que não pode ser negada. Diz-se lá que os brasileiros não gostam de trabalhar, procuram sempre ser "espertos", e, das soluções, optar pelas mais fáceis. Contudo, para que, de fato, se analise com o rigor necessário essa questão, é preciso indagar sobre qual imagem a maior parte dos brasileiros tem deixado vir à tona em Portugal. Seria importante perguntar quem é o brasileiro que emigra hoje, qual o seu perfil e os porquês de sua rejeição no exterior, particularmente quando seu campo profissional nada tem a ver com o samba ou com o futebol.

Sobre a imagem dos portugueses no Brasil, na outra margem, também lidamos, nós, do lado de cá, com cristalizações e preconceitos, que remetem para um português tipificado como burro, curto de raciocínio, objeto de riso público. Por acaso, nós já chegamos a nos perguntar alguma vez como se sente o português imigrante no Brasil quando recebe a avalanche de piadas da pátria que deixou, ou de seus compatriotas? As relações entre os povos são sempre vias de dupla mão. Eduardo Lourenço recorda que os brasileiros recusaram a matriz portuguesa de sua herança histórica. É verdade. Entre a própria intelectualidade, costuma haver todo um culto às imigrações que tiveram lugar desde o final do século passado. Há trabalhos acadêmicos abordando os imigrantes italianos, espanhóis, sírios, alemães, japoneses. A curiosidade sobre a imigração portuguesa parece menor. Até que ponto essa "terra nostra", além de italiana, além de obviamente indígena e africana, também não seria "um pouquinho" portuguesa? Não seria chegada a hora de nos abrirmos, de ambos os lados, para a reciprocidade da redescoberta? Por que recusar a colonização e olhar para essa história exclusivamente para nela visualizar responsabilidades e foros de culpas? Os portugueses, entretanto, também parecem muito reticentes em deixar de evidenciar algum desdém sobre as mazelas de nossa história contemporânea. Talvez haja ainda um "quê" no olhar do colonizador que não é capaz de visualizar o outro apenas como diferente no que se diferencia e semelhante no que se assemelha. Os brasileiros, em contrapartida, também deixam bastante a desejar quando, ao procurar no português, ou o seu "duplo" ou o seu opositor, deixam de observar o que há de mágico no cuidadoso reconhecimento da aproximação "na" e "por causa" da distância.

Seja como for, e ainda que pudesse ser apenas isso, Portugal e Brasil são hoje dois povos irmanados pela mesma língua. $O$ português e o brasileiro conseguem ter a mesma sensibilidade diante de uma poesia de Florbela Espanca ou de Carlos Drummond de Andrade. Afinal, tanto em Portugal quanto no Brasil, sabemos exatamente o sentido ausente da presente palavra "saudade". Quanto à língua portuguesa como uma irrecusável pátria - para recordar Fernando Pessoa -, precisamos ter clareza quanto ao fato de não apenas falarmos uma única e mesma língua, mas sermos, na outra margem, falados/apreendidos também por ela. A língua que nós verbalizamos conta muito do que somos e do modo como nos relatamos. Isso conduz à hipótese de que, entre Portugal e Brasil, a língua comum comunica sentidos e compartilha significados e expressões. Existem, portanto, sentidos inscritos no diálogo; ainda que nem sempre eles estejam já decifrados. Recorrer à "prosa" e ao intercâmbio dos falares Portugal-Brasil será, em meu entendimento, a grande alternativa para superar o histórico fosso do estranhamento. Existe uma pedagogia contida no prospecto de reconhecimento: a pedagogia da linguagem 
comum. Com manifestações mais ou menos explícitas, existe uma identidade coletiva partilhada, ainda que inconsciente. A língua, que comungamos com diferentes sotaques e com algumas licenças gramaticais, fala desse mundo em comum. Talvez esteja aqui a pista para que possamos ir além e seguir adiante.

De resto, como historiadores, chegou o momento de enterrar o passado para poder fazer falar o futuro. $\mathrm{O}$ mundo que está hoje colocado exige desafios maiores do que a prestação de contas com heranças coloniais. A globalização não perdoará os desconhecimentos recíprocos entre os povos. Mais do que nunca, para fazer coro com a metáfora operatória que nos propõe "no mesmo idioma” Rui Martins - entre Portugal e Brasil -, é chegada a hora de edificar concretamente utopias viáveis, tendo em vista um plano de futuro (Martins, 2000) para os dois países onde, afinal, "o puro pássaro é possível” (Belo, 1998, p. 34). Apostar no possível pássaro do futuro é o prospecto imprescindível para agendar tempos de encontros, de ressonâncias, de diálogos, e, nesse interagir, de inevitáveis transformações.

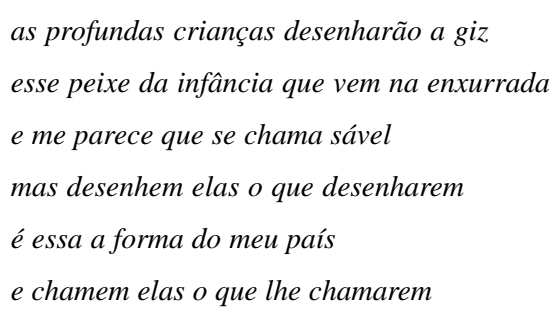

(Ruy Belo, Portugal Futuro, 1998)

CARLOTA BOTO é professora de História da Educação na Universidade Estadual Paulista e na Universidade Presbiteriana Mackenzie, onde atualmente exerce a função de diretora da Faculdade de Filosofia, Letras e Educação. É autora do livro A escola do homem novo, publicado pela Editora da UNESP em 1996.

E-mail: botocarlota@mackenzie.com.br

\section{ReferênciasBibliográficas}

ALBUQUERQUE, Antonio Maria Seabra d', (1870). Selecta da infância: approvada para uso das escholas primarias em sessão da juncta consultiva de Instrucção Publica de 1 de junho de 1870. Coimbra: Imprensa da Universidade.

BELO, Ruy, (1998). País possível. Lisboa: Presença.

CAMÕES, Luís de, (s/d). Os Lusíadas. Porto: Porto Editora.

CARTA de Pero Vaz de Caminha a El-Rei D. Manuel sobre o achamento do Brasil, (1987). Mira-Sintra: Europa América.

CARTAS sobre a educação da mocidade de Ribeiro Sanches, (s/d). Porto: Editorial Domingos Barreira.

CATROGA, Fernando, (1996). História da história em Portugal séculos XIX-XX. Lisboa: Círculo de Leitores.

CERTEAU, Michel de, (1982). A escrita da história. Rio de Janeiro: Forense Universitária. Tradução de Maria de Lourdes Menezes.

COELHO, José Maria Latino, (1857). Encyclopedia das escolas d'instrucção primaria. Lisboa: No Escriptorio de Francisco Arthur da Silva.

COELHO, Trindade, (1903). O terceiro livro de leitura. Lisboa: Livraria Aillaud.

LE GOFF, Jacques, (1997). Documento/Monumento. In: ENCIPLOPÉDIA Einaudi: Memória - História. Lisboa: Imprensa Nacional/Casa da Moeda, v. 1. Tradução de Suzana Ferreira Borges.

LOURENÇO, Eduardo, (1999). A nau de Ícaro: seguido de imagem e miragem da lusofonia. $2^{a}$ ed. Lisboa: Gradiva.

MARTINS, Rui, (2000). Globalização e fronteiras: o paradoxo da demarcação emancipatória. São Paulo: Universidade Presbiteriana Mackenzie (no prelo).

NOVAIS, Fernando A., (1985). Portugal e Brasil na crise do antigo sistema colonial. 3aㅡ. ed. São Paulo: Hucitec.

ORTIGÃO, Ramalho, (1992a). As farpas: aspectos vários da sociedade, da política, da administração, Porto: Clássica Editora, t. X. , (1992b). As farpas: crónica mensal da política, das letras e dos costumes (1871-1872). Porto: Clássica Editora, t. XII. , (1992c). As farpas: crónica mensal da política, das letras e dos costumes (1872). Porto: Clássica Editora, t. XIII.

O PANORAMA: jornal litterario e instructivo da sociedade propagadora dos conhecimentos úteis, (1837-1857). Lisboa: $\mathrm{Na}$ Typographia da Sociedade.

QUEIROZ, Eça de, (1979). A Revolução do Brasil. In: Obras de Eça de Queiroz. Porto: Lello \& Irmão Editores, v. III. 
(s/d-a). A correspondência de Fradique Mendes. Rio de Janeiro: Ediouro.

(s/d-b). O Brasil e Portugal. In: Obras de Eça de Queiroz. Porto: Lello \& Irmão Editores, v. II. , (1987a). Uma campanha alegre I. Mira-Sintra: Europa-América, t. I: “As farpas”.

(1987b). Uma campanha alegre II. Mira-Sintra: Europa-América, t. II: “As farpas”.

SANTOS, Boaventura de Souza, (1993). Modernidade, identidade e cultura de fronteira. Revista crítica de Ciências Sociais: descobrimentos/encobrimentos, $\mathrm{n}^{\circ} 38$, p. 11-39.
SARAIVA, A. J., LOPES, Óscar, (s/d). História da literatura portuguesa. $16^{\mathrm{a}}$ ed. Porto: Porto Editora.

SIMÕES, João Gaspar, (s/d). A Geração de 70. 2ª ed. Lisboa: Editorial Inquérito.

SOUZA, Laura de Mello, (1993). Inferno atlântico: demonologia e colonização - séculos XVI-XVIII. São Paulo: Companhia das Letras.

TESTAMENTO político de D. Luís da Cunha, (1976). São Paulo: Alfa-Ômega.

VIEIRA, (1985). Sermões. 9ª ed. Rio de Janeiro: Agir Editora, v. 11 (org. Eugênio Gomes). 